\title{
Development and Characterization of
} an Improved Ir-0.3\% W Alloy for Space Radioisotopic Heat Sources

\author{
C. T. Liu \\ H. Inouye
}

\section{MASTER}

\section{OAK RIDGE NATIONAL LABORATORY}




\section{DISCLAIMER}

This report was prepared as an account of work sponsored by an agency of the United States Government. Neither the United States Government nor any agency Thereof, nor any of their employees, makes any warranty, express or implied, or assumes any legal liability or responsibility for the accuracy, completeness, or usefulness of any information, apparatus, product, or process disclosed, or represents that its use would not infringe privately owned rights. Reference herein to any specific commercial product, process, or service by trade name, trademark, manufacturer, or otherwise does not necessarily constitute or imply its endorsement, recommendation, or favoring by the United States Government or any agency thereof. The views and opinions of authors expressed herein do not necessarily state or reflect those of the United States Government or any agency thereof. 


\section{DISCLAIMER}

Portions of this document may be illegible in electronic image products. Images are produced from the best available original document. 


\begin{tabular}{|c|}
\hline Printed in the United States of America. Available from \\
National Technical Information Service \\
U.S. Department of Commerce \\
5285 Port Royal Road, Springfield, Virginia 22161 \\
Price: Printed Copy $\$ 4.00 ;$ Microfiche $\$ 3.00$ \\
$4-50$
\end{tabular}

\begin{abstract}
This report was prepared as an account of work sponsored by the United States Government. Neither the United States nor the Energy Research and Development Administration/United States Nuclear Regulatory Commission, nor any of their employees, nor any of their contractors, subcontractors, or their employees, makes any warranty, express or implied, or assumes any legal liability or responsibility for the accuracy, completeness or usefulness of any information, apparatus, product or process disclosed, or represents that its use would not infringe privately owned rights.
\end{abstract}


ORNL-5290

Distribution

Category UC-25

Contract No. W-7405-eng-26

METALS AND CERAMTCS DIVISION

DEVELOPMENT AND CHARACTERIZATION OF AN IMPROVED Ir $-0.3 \% \mathrm{~W}$ ALLOY FOR SPACE RADIOISOTOPIC HEAT SOURCES

C. T. Liu and H. Inouye

Date Published: October 1977

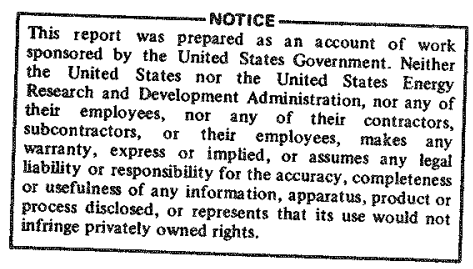

OAK RIDGE NATIONAL LABORATORY

Oak Ridge, Tennessee 37830

operated by

UNION CARBIDE CORPORATION

for the

ENERGY RESEARCH AND DEVELOPMENT ADMINISTRATION 
CONTENTS

ABSTRACT ........................ 1

INTRODUCTION . . . . . . . . . . . . . . . . . . . I

SCREENING STUDY OF DOPED Ir-0.3\% W ALLOYS . . . . . . . . . 4

Selection of Alloying Elements (Dopants) . . . . . . . 4

Alloy Preparation and Fabrication ............ 5

Microstructure and Recrystallization . . . . . . . . 8

Tensile Properties . . . . . . . . . . . . . . 9

SCALE-UP STUDY OF DOP-4 Ir $0.3 \% \mathrm{~W}$. . . . . . . . . . . . 14

CHARACTERIZATION OF IMPACT PROPERTIES OF DOP-4 AND UNDOPED (WG)

ALLOYS . . . . . . . . . . . . . . . . . . . . . . 18

Impact Equipment ............... 18

Impact Results . . . . . . . . . . . . . . 21

Impact Velocity Effect............. 21

Impact Temperature Effects . . . . . . . . . 23

Grain Size Effect . . . . . . . . . . . 25

Long-Term Anneal Effect . . . . . . . . . . . 26

Correlation of Uniaxial Tensile Impact Test with MHW/FSA

Impact Test . . . . . . . . . . . . . . . . 28

GENERAL DISCUSSION ..................... 32

Function of DOP-4 Dopants . . . . . . . . . . . 32

Segregation of the Dopants to Grain Boundaries . . . . 32

Precipitation of Second-Phase Particles . . . . . . . 33

Effects of Grain Size, Dopant Addition, Impact Velocity and

Test Temperature on Impact Properties . . . . . . . . . . . . 34

Grain-Size Effect . . . . . . . . . . . . 35

Dopants Effect................... 36

Test Temperature and Velocity Effects . . . . . . 37

SUMMARY AND CONCLUSTONS . . . . . . . . . . . . 37

ACKNOWLEDGMENTS . . . . . . . . . . . . . . 38 
$\frac{\text { DEVELOPMENT AND CHARACTERIZATION OF AN IMPROVED Ir }-0.3 \% \mathrm{~W} \text { ALLOY }}{\text { FOR SPACE RADIOISOTOPIC HEAT SOURCES }}$

C. T. Liu and H. Inouye

ABSTRACT

An Ir $0.3 \% \mathrm{~W}$ alloy has been doped with minor alloying additions to develope an improved cladding material for space radioisotopic heat sources operating at temperatures to $1450^{\circ} \mathrm{C}$. Tensile tests of a series of doped alloys at slow strain rates indicated that the DOP -4 alloy containing $40 \mathrm{Al}, 30 \mathrm{Th}, 80 \mathrm{Fe}, 10 \mathrm{Ni}$, and $75 \mathrm{Rh}$ ppm was most resistant to the brittle fracture associated with grain-boundary separation. In addition, the DOP -4 dopants raise the recrystallization temperature, and retard grain growth at high temperatures.

The impact properties of DOP-4 and undoped Ir $-0.3 \mathrm{~W}$ alloys were determined as a function of grain size, test temperature, impact velocity and long-term heat treatment. All the results indicate that the impact properties of the DOP-4 alloy are far superior to those of the undoped alloy. The improvement results from the segregation of beneficial dopant(s) (such as thorium) to grain boundaries and precipitation of second-phase particles. The development of the DOP-4 alloy greatly improves the safety margin of the MultiHundred-Watt heat sources to be used in a space probe to Jupiter and Saturn in 1977.

\section{INTRODUCTION}

A multi-hundred watt (MHW) radioisotope heat source for a thermoelectric generator (RTG) has been developed by General Electric (GE) under the sponsorship of the Space Nuclear Systems Division ${ }^{1}$ of ERDA to provide stable electrical power for a variety of space missions (Fig. 1). The heat source $^{2}$ is $18.3 \mathrm{~cm}$ in diameter and $42.9 \mathrm{~cm}$ long, and weighs about $20.4 \mathrm{~kg}$.

\footnotetext{
${ }^{1}$ Presently part of the Division of Nuclear Research and Applications.

${ }^{2}$ General Electric Company, Multi-Hundred Watt Radioisotopic ThermoElectric Generator Progrom, Parts I and II, Annu. Rep. 1 Jan. 197331 Dec. 1973, GESP-7107, GEMS-418.
} 


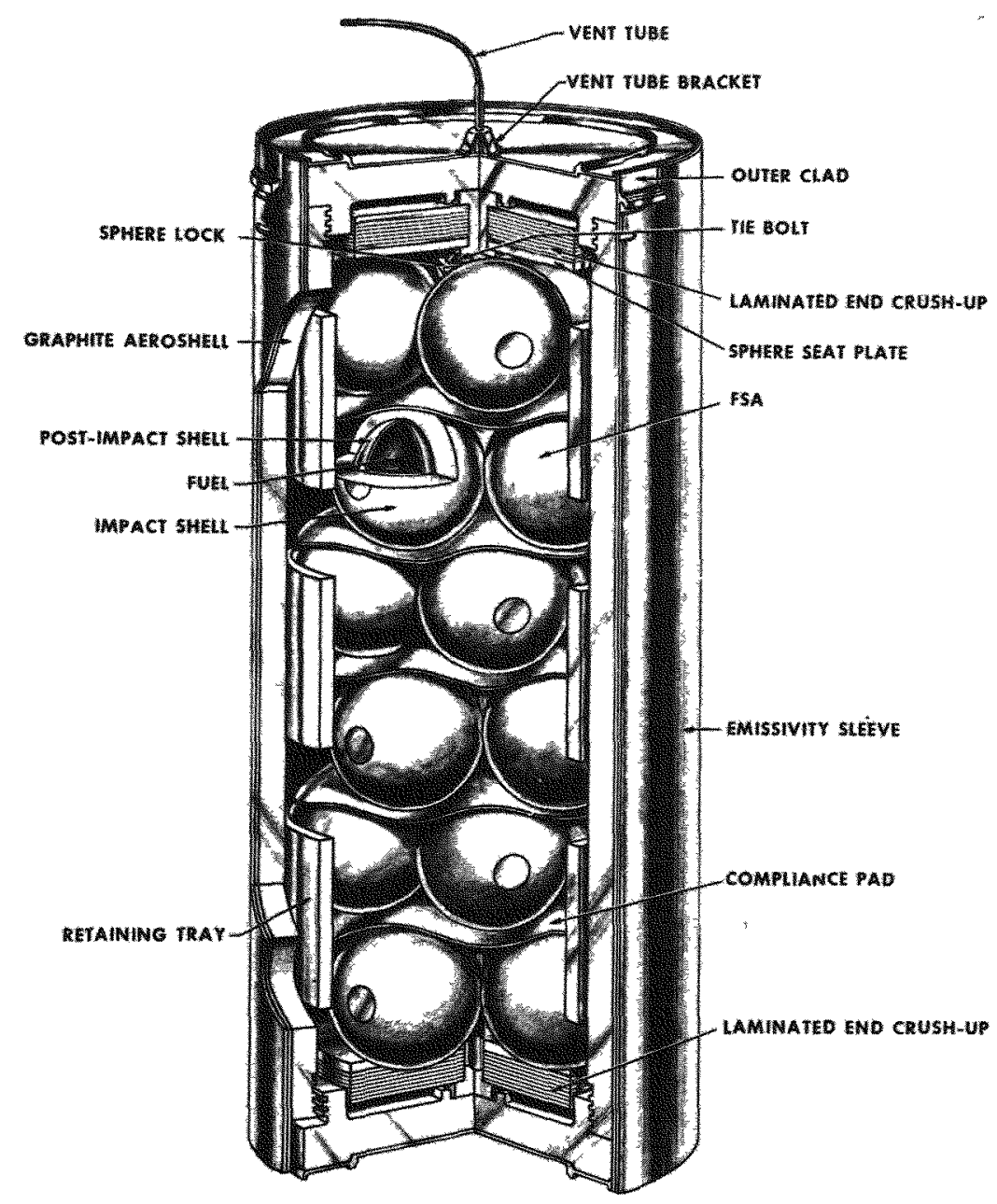

Fig. 1. Multihundred-Watt Heat Source Designed by General Electric Company. Reprinted from General Electric Company, MultiHundred Watt Radioisotopic Thermo-Electric Generator Program, Part I, Annu. Rep. 1 Jan. 1973-31 Dec. 1973, GESP-7107.

It is fueled with 24 fuel sphere assemblies (FSA). The FSA (Fig, 1) has three parts: (1) a $3.81-\mathrm{cm}$-diam ${ }^{238} \mathrm{PuO}_{2}$ fuel ball, (2) a 0.051-cm-thick postimpact containment shel1 (PICS) made of oxidationresistant alloy, and (3) a 1.0-cm-thick thornel graphite impact shell (GIS). The fuel-cladding is designed for an operating temperature around $1330^{\circ} \mathrm{C}$. The electrical power is generated by silicon-Germanium thermoelectric elements attached to the outer can of the heat source. An alloy of Ir $-0.3 \% \mathrm{~W}$ is currently used as PICS material in the MHW heat source because of the alloy's high melting point, good oxidation 
resistance and proven compatibility with fuel and graphite to $1450^{\circ} \mathrm{C}$. Tungsten, at a level of $0.3 \%$, is added to increase the recrystallization temperature and improve the fabricability of iridium. A detailed description of the production of $\mathrm{Ir}-0.3 \% \mathrm{~W}$ sheets and disks for fuel cladding in the MHW heat source has been reported. ${ }^{3}$

On tensile testing at conventional strain rates $\left(10^{-4} \mathrm{~m} / \mathrm{s}\right)$, the $\operatorname{Ir}-0.3 \% \mathrm{~W}$ alloy has been found to be ductile at temperatures above $1000^{\circ} \mathrm{C}^{4}$ The alloy specimens had more than $50 \%$ tensile elongation and fractured by ductile rupture with close to $100 \%$ reduction of area. To simulate the accident conditions of earth impact after orbital abort and atmosphere reentry situation, the FSA/MHW have been impact tested at $1370^{\circ} \mathrm{C}$ at a velocity of $90 \mathrm{~m} / \mathrm{s}(300 \mathrm{fps})$ at GE and Los Alamos Scientific Lab (LASL). Their results indicates ${ }^{2,5}$ that the Ir-0.3\% W PICS sometimes survive the impact test but quite often showed brittle cracking with limited deformation even at a temperature of $1450^{\circ} \mathrm{C}$. In the more severe cases, the cracking leads to a breach of the containment shell which could release small quantities of radioactive fuel. Because of the marginal impact resistance of the $\operatorname{Ir}-0.3 \% \mathrm{~W}$, there is a need to improve the impact properties of the alloy to increase the safety margin of the space heat sources.

Posttest examination of iridium-tungsten PICS revealed ${ }^{2,5,6}$ that the fracture mode of these cracks was mainly intergranular on impact at $90 \mathrm{~m} / \mathrm{s}$ at $1400^{\circ} \mathrm{C}$. The same fracture mode was also observed $^{4}$ at slow strain-rate tests at temperatures below $800^{\circ} \mathrm{C}$. Surface analyses by Auger and spark-source mass spectrometry indicated no major segregation of impurities on the grain boundary,

${ }^{3}$ D. N. Braski and A. C. Schaffhauser, Production of Ir-0.3\% W Disks and FoiZ, ORNL-TM-4865 (April 1975).

${ }^{4} \mathrm{C}$. T. Liu and H. Inouye, Study of Iridium and Iridium-Tungsten Alloys for Space Radioisotopic Heat Sources, ORNL-5240 (December 1976).

${ }^{5}$ R. D. Baker, Los Alamos Scientific Lab., private communications during 1974-1976.

${ }^{6} \mathrm{C}$. T. Liu and H. Inouye, Postmortem Analysis of Ir-2\% W PostImpact Containment ShelI, ORNL-TM-4943 (July 1975). 
suggesting that the grain-boundaries in these high-purity iridium and $\operatorname{Ir}-0.3 \% \mathrm{~W}$ alloys are intrinsically weak. The purpose of this present work was to improve the impact properties of $\mathrm{Ir}-3 \% \mathrm{~W}$ alloy through control of the grain boundary chemistry and minor alloying elements (without sacrificing the other desirable properties). In this study, selected alloying additions (dopants) in the ppm (by weight) range were added to the $\mathrm{Ir}-0.3 \% \mathrm{~W}$ alloy. To characterize the impact properties of the doped alloys, impact equipment has been developed at ORNL, which is capable of testing sheet specimens in controlled atmospheres at $1400^{\circ} \mathrm{C}$ at velocities to $90 \mathrm{~m} / \mathrm{s}$ (300 fps).

SCREENING STUDY OF DOPED Ir-0.3\% W ALLOYS

\section{Selection of Alloying Elements (Dopants)}

The selection of dopants for this study was based on the following considerations:

a. Previous study ${ }^{4}$ of tensile fracture behavior of $\operatorname{Ir}$ and $\operatorname{Ir}-\mathrm{W}$ alloys revealed that alloys containing higher levels of $\mathrm{Th}, \mathrm{A} 1, \mathrm{Fe}, \mathrm{Ta}$, $\mathrm{Ni}$, and Rh were more resistant to grain boundary fracture. Furthermore, the concentrations of $\mathrm{Th}, \mathrm{Ta}, \mathrm{Fe}$, and $\mathrm{Al}$ were much higher near the grain-boundary than in the bulk, suggesting the possibility of segregation of these elements to the grain boundary. These elements may act synergistically to facilitate grain boundary segregation, so they were added as a group to the $\operatorname{Ir}-0.3 \% \mathrm{~W}$ alloy.

b. Some early work ${ }^{7-9}$ on iridium polycrystals suggested that the brittleness in iridium is due to segregation of interstitials on the grain boundaries. If it is the case, alloying iridium with an active component, such as hafnium, may scavenge interstitials from the boundary as well as from the matrix by precipitation.

\footnotetext{
${ }^{7}$ M. A. Fortes and B. Ralph, "A Field-Iron Microscope Study of Segregation to Grain Boundaries In Iridium," Acta. Met. 15: 707 (1976).

${ }^{8}$ Personal communication from P. W. Palmbert to R. L. Mehan, General Electric Company, Philadelphia, December, 9, 1971.

${ }^{9} \mathrm{C}$. A. Brookes, J. H. Greenwood, and J. L. Routbort, "The HighTemperature Tensile Properties of Iridium Single Crystals," J. Inst. Met. 98: 27 (1970).
} 
c. Yttrium is the most common element used for improving grain-boundary
properties in metals and alloys.

Alloy Preparation and Fabrication

The iridium powders (Iots WC and WG) used to prepare doped $\mathrm{Ir}-0.3 \% \mathrm{~W}$ alloys were obtained from U.S. Office of Emergency Preparedness. The chemical analysis by spark source mass spectrometric methods indicated ${ }^{3}$ that these powders were quite pure with total impurities less than $300 \mathrm{ppm}$ by wt. The major impurities were $\mathrm{Ca}, \mathrm{Si}, \mathrm{Cl}$, and $\mathrm{Rh}$; most of the volitle impurities are removed during melting. Two series of doped alloys were prepared with nominal concentrations of dopants (Table 1). The tungsten and dopants (except for hafnium and yttrium) in powder form were thoroughly mixed with iridium powders, followed by cold pressing into compacts. The compacts were sintered in hydrogen at $1000^{\circ} \mathrm{C}$ for one hour and vacuum sintered at $1300^{\circ} \mathrm{C}$ for $3 \mathrm{hr}$. The sintered compacts were then arc-melted six times and cast into rectangular-shaped ingots about $0.8 \times 2.5 \times 5.1 \mathrm{~cm}$, weighing about $150 \mathrm{~g}$. For the doped alloys DOP -11 and -12 , the hafnium and yttrium lumps were added to the Ir $-0.3 \% \mathrm{~W}$ during arc-melting. A few white

Table 1. Nominal Concentration of Dopants in $\operatorname{Ir}-0.3 \% \mathrm{~W}$ Alloys

\begin{tabular}{|c|c|c|c|c|c|c|c|c|}
\hline \multirow{2}{*}{ Alloy } & \multicolumn{8}{|c|}{ Dopants, ppm by weight } \\
\hline & Th & A1 & $\mathrm{Fe}$ & $\mathrm{Ta}$ & $\mathrm{Ni}$ & Rh & $\mathrm{Y}$ & $\mathrm{Hf}$ \\
\hline \multicolumn{9}{|c|}{ First Series } \\
\hline Dop-1 & 30 & 40 & 80 & 31 & 16 & 75 & & \\
\hline 2 & 30 & & 80 & 31 & 16 & 75 & & \\
\hline 3 & 30 & 40 & & 31 & 16 & 75 & & \\
\hline 4 & 30 & 40 & 80 & & 16 & 75 & & \\
\hline 5 & & 40 & 80 & 31 & 16 & 75 & & \\
\hline \multicolumn{9}{|c|}{ Second Series } \\
\hline 7 & 60 & 80 & 160 & & 32 & 150 & & \\
\hline 8 & 90 & 120 & 240 & & 48 & 225 & & \\
\hline 10 & 200 & 40 & 80 & & 16 & 75 & & \\
\hline 11 & & & & & & & 150 & \\
\hline 12 & & & & & & & & 200 \\
\hline
\end{tabular}


ceramic-1ike globules were observed on the top surface of the ingot DOP-8, but not on the rest of the ingots. The globules are most probably complex oxides and were insoluble in hot $\mathrm{NaOH}$, aqua regia, and hafnium solutions. One half of ingot DOP-10 was badly contaminated with copper during casting, and so was not used. Alloys DOP -7 and -8 contain double and triple concentrations of the dopants in DOP-4 (referred to as DOP-4 dopants). DOP-10 contains $170 \mathrm{ppm}$ Th plus DOP-4 dopants.

The as-cast alloy ingots were first cleaned in a solution of aqua regia plus $15 \% \mathrm{HF}$ solution for about $30 \mathrm{~min}$, and were next clad in molybdenum jackets and sealed by electron-beam welding. The assemblies were then heated at $1200-1250^{\circ} \mathrm{C}$ under a partial argon atmosphere and rolled with $15-18 \%$ reduction per pass and a 10-minreheating period. After a total of $65 \%$ reduction, the alloy plates ( $0.25-\mathrm{cm}$-thick) were removed from the molybdenum jacket and cleaned electrolytically in $\mathrm{KCN}$ solution. After recrystallizing for $1 \mathrm{hr}$ at $1300-1400^{\circ} \mathrm{C}$ the alloy plates were wrapped in loose-fitting molybdenum cover sheet and further rolled at 900 to $1100^{\circ} \mathrm{C}$ to 0.6-mm-thick sheets. The finished sheets generally exhibited some minor edge and end cracks, except for DOP-11 which showed severe edge and surface cracks. Microscopic examination indicates that the surface cracks on sheet DOP-11 were formed along grain boundaries. This observation suggests that alloying Ir $-0.3 \%$ W with $150 \mathrm{ppm} \mathrm{Y}$ has a detrimental effect on its grain boundary ductility and fabrication properties. Thus, the DOP-11 sheet was not used for further evaluations.

Chemical compositions of the doped alloys as determined by the SSMS analysis show that the dopant levels correlate reasonably well with the nominal concentrations in the alloys prepared by arcmelting (Table 2). The Al, Th, and Fe contents are lower than the nominal amount, possibly due to loss through evaporation or formation of glassy globules (as observed on the ingot DOP-8). The alloy DOP -8 picked up a significant amount of iron, and DOP-10 iron and copper during arc melting and casting. These alloys had a low level of 
Table 2. Chemical Analysis ${ }^{a}$ of Doped Ir $-0.3 \% \mathrm{~W}$ Alloy Sheets

\begin{tabular}{|c|c|c|c|c|c|c|c|c|c|c|c|}
\hline \multirow{2}{*}{ Element } & \multicolumn{5}{|c|}{ First Series of Doped Alloys } & \multicolumn{4}{|c|}{ Second Series of Doped Alloys } & \multirow{2}{*}{$\frac{\text { Scaled-up A11oy }}{\text { Dop-4-1 }}$} & \multirow{2}{*}{$\frac{\text { Undoped A11oy }^{\mathrm{C}}}{\text { WG }}$} \\
\hline & DOP -1 & DOP-2 & DOP -3 & DOP-4 & DOP-5 & $\mathrm{DOP}-7$ & DOP-8 & DOP-10 & DOP -12 & & \\
\hline$A 1^{\mathrm{d}}$ & 20 & 10 & 20 & 20 & 20 & 70 & 100 & 100 & 10 & 10 & 5 \\
\hline B & 3 & 0.1 & 0.1 & 0.1 & 0.1 & $<0.1$ & $<0.1$ & $<0.1$ & 0.1 & 0.5 & 0.5 \\
\hline $\mathrm{Ca}$ & 0.3 & 0.5 & 0.1 & 0.1 & 0.6 & 1 & 0.3 & 10 & 1 & 1 & 1 \\
\hline Co & 1 & 1 & 1 & 1 & 1 & 1 & 1 & 1 & 1 & $<0.3$ & 0.1 \\
\hline $\mathrm{Cr}$ & 5 & 3 & 15 & 15 & 5 & 20 & 3 & 3 & 3 & $\leqslant 3$ & 55 \\
\hline $\mathrm{Cu}$ & 1 & 7 & 7 & 7 & 20 & 15 & 15 & 150 & 50 & 20 & 1 \\
\hline $\mathrm{Fe}^{\mathrm{d}}$ & 50 & 50 & 10 & 50 & 50 & 150 & 600 & 200 & 100 & 15 & 5 \\
\hline $\mathrm{HF}^{\mathrm{d}}$ & $<0.3$ & $<0.3$ & $<0.3$ & $<0.3$ & $<0.3$ & $<0.3$ & $<0.3$ & $<0.3$ & 120 & $<0.3$ & $<0.3$ \\
\hline $\mathrm{Mn}$ & 0.3 & 0.5 & 0.5 & 0.5 & 0.5 & 1 & 3 & 3 & 0.5 & 0.3 & 0.1 \\
\hline $\mathrm{Ni}$ & 20 & 10 & 20 & 20 & 20 & 50 & 60 & 20 & 5 & 5 & 1 \\
\hline $\mathrm{P}$ & 0.1 & 0.1 & 0.1 & 0.1 & 0.3 & 0.3 & 0.3 & 0.3 & $<0.1$ & & \\
\hline $\mathrm{Pt}^{\mathrm{d}}$ & 15 & 10 & 20 & 30 & 15 & 10 & 30 & 20 & 20 & & \\
\hline $\mathrm{Rh}^{\mathrm{d}}$ & 80 & 80 & 80 & 100 & 100 & 100 & 200 & 150 & 10 & 70 & 20 \\
\hline $\mathrm{Ru}$ & 15 & 15 & 15 & 15 & 15 & 1 & 10 & 10 & 20 & 50 & 20 \\
\hline Si & 15 & 15 & 15 & 40 & 15 & 3 & 100 & 30 & 10 & 5 & 5 \\
\hline $\mathrm{Ta}^{\mathrm{d}}$ & 20 & 30 & 20 & 10 & 40 & 50 & 20 & 20 & 10 & 10 & 10 \\
\hline $\mathrm{Th}^{\mathrm{d}}$ & 15 & 20 & 15 & 15 & $<0.5$ & 50 & 60 & 120 & $<1$ & 20 & $<0.1$ \\
\hline \multicolumn{12}{|l|}{$w^{e}$} \\
\hline $\mathrm{Y}^{\mathrm{d}}$ & $<0.1$ & $<0.1$ & $<0.1$ & $<0.1$ & $<0.1$ & $<0.1$ & $<0.1$ & $<0.1$ & $<0,1$ & $<0,1$ & $<0.1$ \\
\hline
\end{tabular}

${ }^{a}$ Analysis in parts per million by spark source mass spectrometric method.

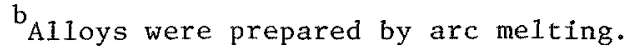

${ }^{c}$ Alloys were prepared by electron-beam melting.

dDopant elements with nominal concentration.

Assumed to be $30.00 \mathrm{ppm}$ in a11 material. 
interstitial impurities (Table 3) and were not significantly different from the electron-beam melted, undoped $\operatorname{Ir}-0.3 \% \mathrm{~W}$ alloy.

\section{Microstructure and Recrystallization}

The doped alloy sheets produced by warm-rolling between $900-1100^{\circ} \mathrm{C}$ had a fibruous microstructure, Occasionally, a few small recrystallized grains were observed. The sheet specimens of DOP -1 and -4 were vacuum heat-treated for $1 \mathrm{hr}$ at temperatures between 800 and $1600^{\circ} \mathrm{C}$ to study their recrystallization and microstructure. The recrystallization temperatures were determined metallographically (Table 4) and compared with those for undoped $\mathrm{Ir}-0.3 \% \mathrm{~W}$. The recrystallization of the undoped alloy started at $870^{\circ} \mathrm{C}$ and was complete at $1070^{\circ} \mathrm{C}$ for 1 hr heat treatments. However, the recrystallization temperatures of the two alloys with a total of $240-270 \mathrm{ppm}$ dopants were $150^{\circ} \mathrm{C}$ higher. Thus, the recrystallization behavior of Ir $0.3 \% \mathrm{~W}$ is sensitive to the trace elements in the parts per million range.

The recrystallized doped alloys had a few second-phase particles distributed uniformly throughout the grains. The doped alloys had an elongated grain structure when recrystallized which became equiaxed after heat treatments above $1500^{\circ} \mathrm{C}$.

Table 3. Interstitial Content of Doped Ir $-0.3 \% \mathrm{~W}$ Alloys

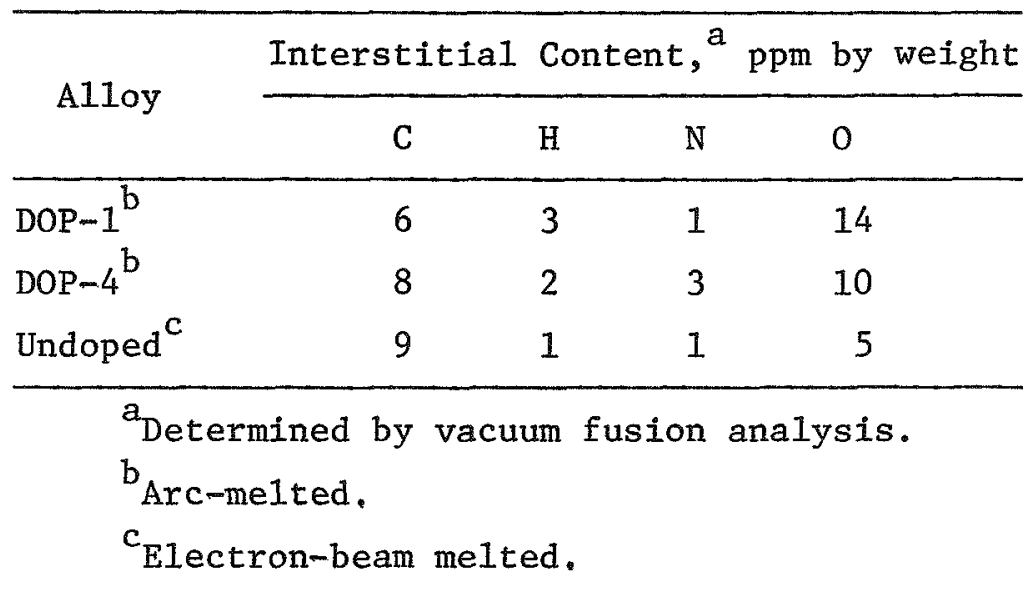


Table 4. Effect of $1 \mathrm{hr}$ Heat-Treatment on the Recrysta11ization of DOP-1, DOP-4, and Undoped Ir-0.3\% W A11oys

\begin{tabular}{lcc}
\hline \multirow{2}{*}{ A11oy } & $\begin{array}{r}\text { Temperature for Indicated Percentage } \\
\text { of Recrystallization, }{ }^{\circ} \mathrm{C}\end{array}$ \\
\cline { 2 - 3 } & $0 \%^{\mathrm{b}}$ & $100 \%^{\mathrm{b}}$ \\
\hline DOP-1 & 1000 & 1230 \\
DOP-4 & 1000 & 1230 \\
Undoped & 870 & 1070 \\
\hline \multicolumn{2}{c}{ a Warm ro1led between $_{\text {900-1100 }}{ }^{\circ} \mathrm{C}}$. \\
$\mathrm{b}_{\text {Percent of recrystallization. }}$
\end{tabular}

Tensile Properties

Specimens with a gage section of $0.318 \mathrm{~cm}$ wide by $1.3 \mathrm{~cm}$ long and with a $0.310-\mathrm{cm}$-diam pin hole were blanked from $0.05-0.08$-cm-thick stock for tensile testing. The blanked specimens were polished on 400-A SiC paper, pickled in an aqua regia plus HF solution, then heat-treated for $1 \mathrm{hr}$ at $1500^{\circ} \mathrm{C}$ in vacuum. Tensile specimens tested above room temperature were heated by radiation from an inductively heated tantalum susceptor under a vacuum of less than $1 \times 10^{-3} \mathrm{~Pa}$. A Pt vs Pt-10\% Rh thermocouple centrally located in the specimen monitored the temperature. After a 15-min holding time at the test temperature, tests were made on an Instron testing machine at a strain rate of $0.26-0.51 \mathrm{~cm} / \mathrm{min}(0.1-0.2 \mathrm{in.} / \mathrm{min})$.

The tensile properties of the first series of doped alloys were measured at room temperatures, $650,760,1093$, and $1370^{\circ} \mathrm{C}$ (Table 5); and compared with undoped Ir-0.3\% $\mathrm{W}$ alloy (lots WG and WC) prepared from electron-beam melted and drop-cast ingots. The yield strength of the doped alloys DOP-1 to -5 is higher than that of the undoped alloy by about $50 \%$ at all test temperatures. Alloys DOP-1 to -4 had the same level of tensile strength and elongation as the undoped alloy. The elongation of DOP-5 containing no thorium was lower than the alloys doped with $30 \mathrm{ppm}$ Th. 
Table 5. Tensile Properties ${ }^{a}$ of the First Series of Ir-0.3\% W Alloys ${ }^{b}$

\begin{tabular}{|c|c|c|c|c|}
\hline \multirow{2}{*}{ Alloy } & \multicolumn{2}{|c|}{ Strength, MPa (ksi) } & \multirow{2}{*}{$\begin{array}{c}\text { E1ongation } \\
(\%)\end{array}$} & \multirow{2}{*}{ Fracture Mode ${ }^{c}$} \\
\hline & Yield & Tensile & & \\
\hline \multicolumn{5}{|c|}{ Room Temperature } \\
\hline Undoped $(W C)^{\mathrm{d}}$ & $84.8(12.3)$ & $400.3(58.1)$ & 12.9 & Mainly GBS \\
\hline Undoped (WG) ${ }^{\mathrm{d}}$ & $81.3(11.8)$ & $431.3(62.6)$ & 14.2 & Mainly GBS \\
\hline $\mathrm{DOP}-1^{\mathrm{e}}$ & $121.2(17.6)$ & $427.9(62.1)$ & 12.2 & Mainly GBS \\
\hline$-2^{e}$ & $103.4(15.0)$ & $347.3(50.4)$ & 10.4 & Mainly GBS \\
\hline$-3^{e}$ & $110.2(16.0)$ & $416.9(60.5)$ & 11.6 & Mainly GBS \\
\hline$-4^{e}$ & $120.6(17.5)$ & $445.1(64.6)$ & 13.1 & Mainly GBS \\
\hline$-5^{\mathrm{e}}$ & $117.8(17.1)$ & $381.7(55.4)$ & 10.3 & Mainly GBS \\
\hline \multicolumn{5}{|c|}{$650^{\circ} \mathrm{C}$} \\
\hline Undoped (WC) & $65.5(9.5)$ & $414.1(60.1)$ & 23.3 & Mainly GBS \\
\hline Undoped (WG) & $51.0(7.4)$ & $487.8(70.8)$ & 30.1 & Mainly GBS \\
\hline DOP -1 & $97.1(14.1)$ & $492.6(71.5)$ & 29.4 & $\mathrm{TF}(\mathrm{Ma})$ and $\mathrm{GBS}$ (Mi) \\
\hline-2 & $79.9(11.6)$ & $458.9(66.6)$ & 25.9 & $\mathrm{TF}(\mathrm{Ma})$ and $\mathrm{GBS}$ (Mi) \\
\hline-3 & $83.4(12.1)$ & $471.9(68.5)$ & 27.6 & $\mathrm{TF}(\mathrm{Ma})$ and $\mathrm{GBS}(\mathrm{Mi})$ \\
\hline-4 & $96.5(14.0)$ & $462.3(67.1)$ & 31.7 & Mainly $T F$ \\
\hline-5 & $96.5(14.0)$ & $436.1(63.3)$ & 22.2 & $\mathrm{TF}$ and $\mathrm{GBS}$ \\
\hline \multicolumn{5}{|c|}{$760^{\circ} \mathrm{C}$} \\
\hline Undoped (WC) & $61.3(8.9)$ & $445.1(64.6)$ & 39.8 & $\mathrm{GBS}$ and $\mathrm{TF}$ \\
\hline Undoped (WG) & $46.9(6.8)$ & $441.0(64.0)$ & 39.3 & GBS (Ma) and $\mathrm{TF}$ (Mi) \\
\hline DOP -1 & $106.1(15.4)$ & $450.6(65.4)$ & 37.9 & TF \\
\hline-2 & $94.4(13.7)$ & $423.7(61.5)$ & 38.2 & TF \\
\hline-3 & $95.1(13.8)$ & $425.1(61.7)$ & 33.1 & $\mathrm{TF}$ \\
\hline-4 & $100.6(14.6)$ & $425.8(61.8)$ & 35.2 & $\mathrm{TF}$ \\
\hline-5 & $83.4(12.1)$ & $414.1(60.1)$ & 27.3 & Mainly $\mathrm{TF}$ \\
\hline \multicolumn{5}{|c|}{$1093^{\circ} \mathrm{C}$} \\
\hline Undoped (WC) & $44.8(6.5)$ & $276.3(40.1)$ & 57.6 & $\mathrm{DR}$ \\
\hline Undoped (WG) & $46.2(6.7)$ & $249.4(36.2)$ & 55.6 & DR \\
\hline DOP-1 & $63.4(9.2)$ & $281.1(40.8)$ & 49.4 & $\mathrm{DR}$ \\
\hline-2 & $58.6(8.5)$ & $275.6(40.0)$ & 45.2 & $\mathrm{DR}$ \\
\hline-3 & $68.2(9.9)$ & $261.8(38.0)$ & 52.9 & $\mathrm{DR}$ \\
\hline-4 & $69.6(10.1)$ & $254.9(37.0)$ & 48.2 & $\mathrm{DR}$ \\
\hline-5 & $62.7(9.1)$ & $260.4(37.8)$ & 42.3 & DR \\
\hline \multicolumn{5}{|c|}{$1370^{\circ} \mathrm{C}$} \\
\hline Undoped (WC) & $34.5(5.0)$ & $181.2(26.3)$ & 54.2 & $\mathrm{DR}$ \\
\hline Undoped (WG) & $38.6(5.6)$ & $177.8(25.8)$ & 55.2 & $\mathrm{DR}$ \\
\hline DOP-1 & $73.0(10.6)$ & $190.9(27.7)$ & 54.4 & $\mathrm{DR}$ \\
\hline-2 & $50.3(7.3)$ & $185.3(26.9)$ & 52.9 & $\mathrm{DR}$ \\
\hline-3 & $51.0(7.4)$ & $181.9(26.4)$ & 56.0 & $\mathrm{DR}$ \\
\hline-4 & $53.1(7.7)$ & $181.9(26.4)$ & 52.2 & $\mathrm{DR}$ \\
\hline-5 & $56.5(8.2)$ & $177.1(25.7)$ & 45.0 & $\mathrm{DR}$ \\
\hline
\end{tabular}

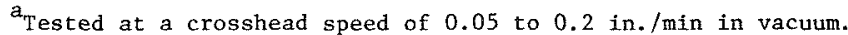

${ }^{b}$ Sheet specimens were annealed $1 \mathrm{hr}$ at $1500^{\circ} \mathrm{C}$ before testing.

$c_{G B S}=$ grain-boundary separation, $T F=$ transgranular fracture, $D R=$ ductile rupture, $M i=$ minor fraction, and $M a=$ major fraction .

$d_{\text {Undoped alloy prepared by electron-beam melting and drop casting. }}$

Eoped alloy prepared by arc melting and regular casting. 
Fracture surfaces were examined by optical and/or scanning electron microscopy. The doped and undoped alloys had primarily grain-boundary separation (GBS) at room temperature; however, the doped alloys had more transgranular fracture (TF). At $650^{\circ} \mathrm{C}$, GBS was still the dominant mode of fracture for the undoped alloy [Fig. 2(a)], while mainly TF or mixture of TF (major) and GBS (minor) was the fracture mode for the doped alloys. The DOP-4 (containing no tantalum) is the only doped alloy showing mainly TF fracture at $650^{\circ} \mathrm{C}$ [Fig. 2(b)]. At $760^{\circ} \mathrm{C}$, the undoped alloy showed a mixture of
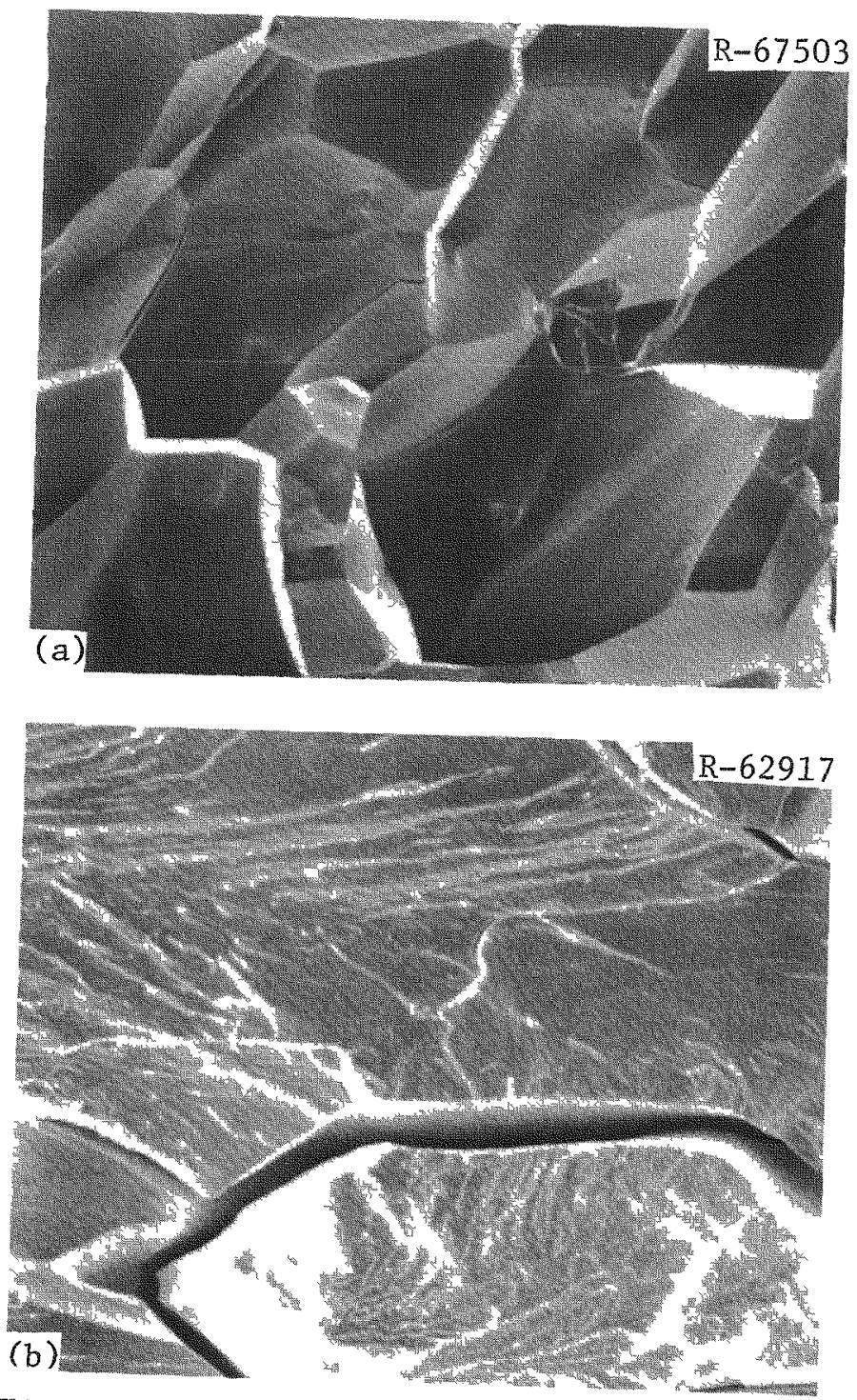

Fig. 2. SEM Fractograph of Tensile Specimens Fractured at $650^{\circ} \mathrm{C}$; (a) Undoped WG, and (b) DOP -4 . 300\%. 
GBS and TF, while the doped alloys DOP-1 to -4 exhibited almost complete $\mathrm{TF}$. The intergranular fracture was not observed at higher temperatures; in fact, all alloys, whether doped or not, exhibited ductile rupture with reduction in area close to $100 \%$ at 1093 and $1370^{\circ} \mathrm{C}$.

Four important correlations can be made between the fracture behavior and dopant composition (Table 5):

1. Doping of $\operatorname{Ir}-0.3 \% \mathrm{~W}$ with small amounts of $\mathrm{Al}, \mathrm{Fe}, \mathrm{Ta}, \mathrm{Th}, \mathrm{Ni}$ and $\mathrm{Rh}$ at a level less than $100 \mathrm{ppm}$ apparently affects the mechanical properties of the grain boundary and suppresses intergranular fracture at lower temperatures.

2. Test results (Table 5) suggest that several elements rather than just one may contribute to the overall change in the fracture mode.

3. The element which most effectively suppresses GBS in $\mathrm{Ir}-0.3 \%$ is thorium, while the element which may have a detrimental effect is tantalum.

4. The alloy with most resistance to GBS is DOP-4 which was doped with $40 \mathrm{ppm} \mathrm{Al}, 80 \mathrm{Fe}, 30 \mathrm{Th}, 16 \mathrm{Ni}$, and $75 \mathrm{Rh}$.

To determine the optimum amount of DOP-4 dopants, a second series of doped alloys was prepared (Table 1 ). DOP -7 and -8 contained double and triple the amounts of DOP -4 dopants, respectively. The nominal amount of thorium (the most beneficial dopant) was increased in DOP-10 (200 ppm) compared to DOP-4 (30 ppm). Unfortunately the DOP-10 alloy was contaminated with copper and iron during arc-melting. The fracture behavior (in terms of percent of TF) of DOP $-7,-8,-10$, and -12 (doped with $200 \mathrm{ppm}$ Hf alone) can be compared with that of DOP- 4 and the undoped alloy at 650 and $760^{\circ} \mathrm{C}$, the temperatures where the fracture mode is most sensitive (Fig. 3). The DOP-4 alloy is most resistant to intergranular fracture at these two temperatures (Fig. 3). Thus, the optimum concentration of dopants should be somewhere around the DOP-4 levels. The fracture behavior of DOP-12 is not different from the undoped alloy, indicating that doping with $200 \mathrm{ppm}$ Hf does not improve the fracture behavior of Ir $-0.3 \% \mathrm{~W}$ alloy. 
Table 6. Tensile Properties of DOP-4 and Undoped Ir $-0.3 \% \mathrm{~W}$ Alloys ${ }^{\mathrm{a}}$ Fabricated from the Same Iridium Powder (WG)

\begin{tabular}{|c|c|c|c|c|}
\hline \multirow{2}{*}{ Heat } & \multicolumn{2}{|c|}{ Strength, MPa (ksi) } & \multirow{2}{*}{$\underset{(\%)}{\text { Elongation }}$} & \multirow{2}{*}{ Fracture Mode } \\
\hline & Yield & Tensile & & \\
\hline \multicolumn{5}{|c|}{ Room Temperature } \\
\hline $\begin{array}{l}\text { WG- } 202^{\mathrm{C}} \\
\text { DOP-4-1 } \\
\text { DOP }-4-3^{\mathrm{e}}\end{array}$ & $\begin{aligned} 81.3 & (11.8) \\
108.9 & (15.8) \\
95.1 & (13.8)\end{aligned}$ & $\begin{array}{ll}431.3 & (62.6) \\
500.2 & (72.6) \\
485.1 & (70.4)\end{array}$ & $\begin{array}{l}14.2 \\
15.3 \\
15.6\end{array}$ & $\begin{array}{l}\text { Mainly GBS } \\
\text { Mainly GBS } \\
\text { Mainly GBS }\end{array}$ \\
\hline \multicolumn{5}{|c|}{$650^{\circ} \mathrm{C}$} \\
\hline $\begin{array}{l}\text { WG-202 } \\
\text { DOP }-4-1 \\
\text { DOP }-4-3\end{array}$ & $\begin{array}{ll}51.0 & (7.4) \\
68.9 & (10.0) \\
64.1 & (9.3)\end{array}$ & $\begin{array}{ll}487.8 & (70.8) \\
553.3 & (80.3) \\
542.9 & (78.8)\end{array}$ & $\begin{array}{l}30.1 \\
36.0 \\
35.7\end{array}$ & $\begin{array}{l}\text { Mainly GBS } \\
\text { GBS (Ma) and TF (Mi) } \\
\text { GBS (Ma) and TF (Mi) }\end{array}$ \\
\hline \multicolumn{5}{|c|}{$760^{\circ} \mathrm{C}$} \\
\hline $\begin{array}{l}\text { WG-2O2 } \\
\text { DOP-4-1 } \\
\text { DOP-4-3 }\end{array}$ & $\begin{array}{ll}46.9 & (6.8) \\
60.6 & (8.8) \\
59.3 & (8.6)\end{array}$ & $\begin{array}{ll}441.0 & (64.0) \\
474.0 & (68.8) \\
465.1 & (67.5)\end{array}$ & $\begin{array}{l}39.3 \\
50.0 \\
47.1\end{array}$ & $\begin{array}{l}\text { GBS (Ma) and } \mathrm{TF} \text { (Mi) } \\
\mathrm{TF} \\
\mathrm{TF}\end{array}$ \\
\hline \multicolumn{5}{|c|}{$1093^{\circ} \mathrm{C}$} \\
\hline $\begin{array}{l}\text { WG-202 } \\
\text { DOP }-4-1 \\
\text { DOP }-4-3\end{array}$ & $\begin{array}{ll}46.2 & (6.7) \\
55.8 & (8.1) \\
59.9 & (8.7)\end{array}$ & $\begin{array}{ll}249.4 & (36.2) \\
280.4 & (40.7) \\
268.0 & (38.9)\end{array}$ & $\begin{array}{l}55.6 \\
58.2 \\
58.8\end{array}$ & $\begin{array}{l}\mathrm{DR} \\
\mathrm{DR} \\
\mathrm{DR}\end{array}$ \\
\hline \multicolumn{5}{|c|}{$1370^{\circ} \mathrm{C}$} \\
\hline $\begin{array}{l}\text { WG-202 } \\
\text { DOP-4-1 } \\
\text { DOP }-4-3\end{array}$ & $\begin{array}{ll}38.6 & (5.6) \\
46.2 & (6.7) \\
40.7 & (5.9)\end{array}$ & $\begin{array}{ll}177.8 & (25.8) \\
191.5 & (27.8) \\
187.4 & (27.2)\end{array}$ & $\begin{array}{l}55.2 \\
60.7 \\
58.1\end{array}$ & $\begin{array}{l}\mathrm{DR} \\
\mathrm{DR} \\
\mathrm{DR}\end{array}$ \\
\hline
\end{tabular}

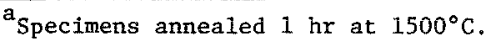

$\mathrm{b}_{\mathrm{GBS}}=$ grain boundary separation; $\mathrm{TF}=$ transgranular fracture; $\mathrm{Ma}=$ major fraction; $M i=$ minor fraction; and $D R=$ Ductile rupture.

$\mathrm{c}_{\text {Undoped }} \mathrm{I}-0.3 \% \mathrm{~W}$ prepared from electron-beam melting and drop casting of WG powder compacts.

$\mathrm{d}_{\text {Doped }}$ Ir $-0.3 \% \mathrm{~W}$ prepared from electron-beam melting and drop casting of WG powder compacts with DOP-4 additions.

Doped Ir $0.3 \% \mathrm{~W}$ prepared from electron-beam melting and drop casting of recycled heads and skulls from ingots, DOP-4, -1 , and -2 .

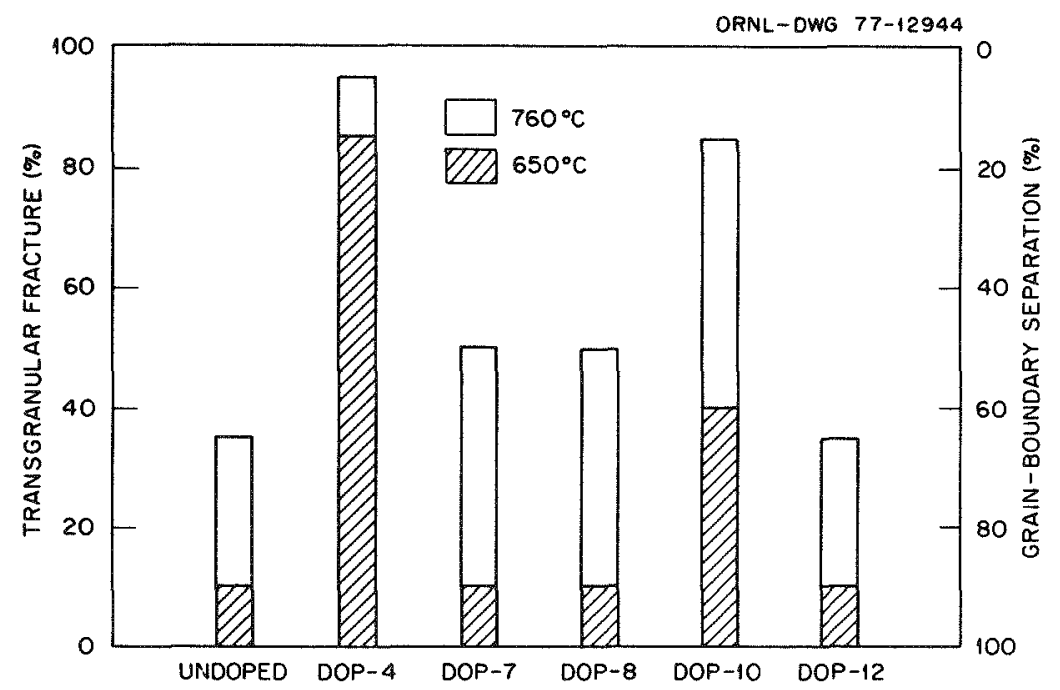

Fig, 3, Fracture Behavior of Doped and Undoped Alloys Tensile Tested at 650 and $760^{\circ} \mathrm{C}$ at Slow Strain Rate $\left(1 \times 10^{-5} \mathrm{~m} / \mathrm{s}\right)$. 
SCALE-UP STUDY OF DOP -4 Ir $-0.3 \% \mathrm{~W}$

The screening study indicated that DOP-4 alloy was most resistant to the brittle grain-boundary fracture, so this alloy was chosen for a scale-up study. The purpose of this study was to further evaluate the alloy's fabricability, metallurigical properties (such as microstructure and grain-growth behavior), tensile properties, and impact behavior. The latter evaluation involved an uniaxial impact test developed at ORNL as well as the FSA-Type impact test required for qualification of the MHW heat source.

Alloy buttons weighing $500 \mathrm{~g}$ were prepared by both arc melting and electron-beam melting of $\mathrm{Ir}-0.3 \% \mathrm{~W}$ sintered compacts with the DOP-4 additions. An examination of the alloy buttons revealed sma11 glassy oxide globules on the surface of arc melted buttons but not on the EB melted buttons. The glassy substance was determined by SSMS to be a complex oxide of mostly $\mathrm{Ca}, \mathrm{Al}$, and $\mathrm{Th}$. Also, the alloy buttons and ingots occasionally picked up high levels of $\mathrm{Fe}, \mathrm{Cu}, \mathrm{Cr}$, $\mathrm{Ni}$, and $\mathrm{P}$ during arc-melting. Because of these problems, the arcmelting method was dropped from the scale-up study.

Four heats of DOP -4 Ir $-0.3 \%$ alloy, designated as DOP $-4-1$ to -4 , were prepared by EB melting and drop-casting into $1.9 \times 1.9 \times 5.4 \mathrm{~cm}$ ingots. The ingots DOP $-4-1$ and -2 were prepared from $100 \%$ sintered compacts, DOP $-4-3$ from $100 \%$ recycled heads and skulls from ingots DOP $-4-1$ and -2, DOP $-4-4$ from $50 \%$ sintered compacts and $50 \%$ recycled skul1 and heads from ingot DOP-4-3. The four ingots were clad in a molybdenum frame and cover plate, and hot-rolled to 0.81 -mm-thick sheets between 850 and $1200^{\circ} \mathrm{C}$ according to the same procedure developed ${ }^{10}$ previously for fabrication of undoped $\mathrm{Ir}-0.3 \% \mathrm{~W}$ sheets used for space flight system hardware. The fabricated sheets were then sectioned a part was used for evaluation of metallurgical and mechanical properties at ORNL; the other parts were further fabricated to $6.03-\mathrm{cm}$-diam by 0.0645-cm-thick blanks for hemishel1 forming at Mound Research Labs (MRL) and for capsule impact test at $\mathrm{GE}$.

${ }^{10}$ D. N. Braski and A. C. Schaffhauser, Production of Irm $0.3 \% \mathrm{~W}$ Disks and Foil, ORNL-TM-4865 (April 1975). 
The microstructure of the DOP-4 sheets was examined metallographically after short-term heat treatments between 1200 and $1800^{\circ} \mathrm{C}$. A comparison of the microstructure of DOP -4 with undoped (WG) specimens heat treated at 1400 and $1500^{\circ} \mathrm{C}$ (Fig. 4) shows that after a $1 \mathrm{hr}$ anneal at 1400 and $1500^{\circ} \mathrm{C}$, the DOP-4 specimens [Fig. 4(b,d)] had an elongated grain structure with some second-phase particles distributed in the grains or on grain boundaries. By comparison, WG specimens [Fig. 4(a,c, and e)] exhibited, more or less, an equiaxed grain sturcture with virtually no precipitate. The degree of grain elongation in DOP-4 alloy decreased with increasing annealing time [Fig. 4(f)] and temperature. The grain size of DOP -4 and WG was measured as a function of heat treatment (see Table 9, p. 25). The DOP-4 alloy always had a finer grain structure than the undoped alloy, indicating that the DOP -4 dopants retarded grain growth in Ir-0.3\% W. There is no major difference in grain structure among the four DOP-4 sheets.

The tensile properties of the DOP -4 sheets DOP $-4-1$ and -3 were measured at a strain rate of $5.1 \mathrm{~mm} / \mathrm{min}\left(\sim 4 \times 10^{-5} \mathrm{~m} / \mathrm{s}\right)$ in vacuum at room and elevated temperatures. The tensile data (Table 6) are compared with those of undoped $\operatorname{Ir}-0,3 \% \mathrm{~W}$ alloy $\mathrm{WG}$ prepared from the same iridium powder and using the same melting and fabrication schedules. The strength and elongation of the DOP -4 sheets are higher than those of the undoped WG, particularly at lower temperatures. The fracture surface of the DOP-4 specimens was examined and compared with WG specimens (Table 6 and Fig. 5). At $760^{\circ} \mathrm{C}$, DOP $-4-1$ showed TF with a high degree of secondary cracking while WG exhibited a mixed fracture mode with GBS as a major fraction. The DOP-4 material is more resistant to the intergranular fracture, confirming the results obtained from the primary study (Table 5). However, due possibly to a loss of a part of low-melting dopants (SSMS analysis, Table 2) on EB melting, the improvement of fracture behavior at $650^{\circ} \mathrm{C}$ is less than that of the DOP -4 alloy prepared from arc-melting. 

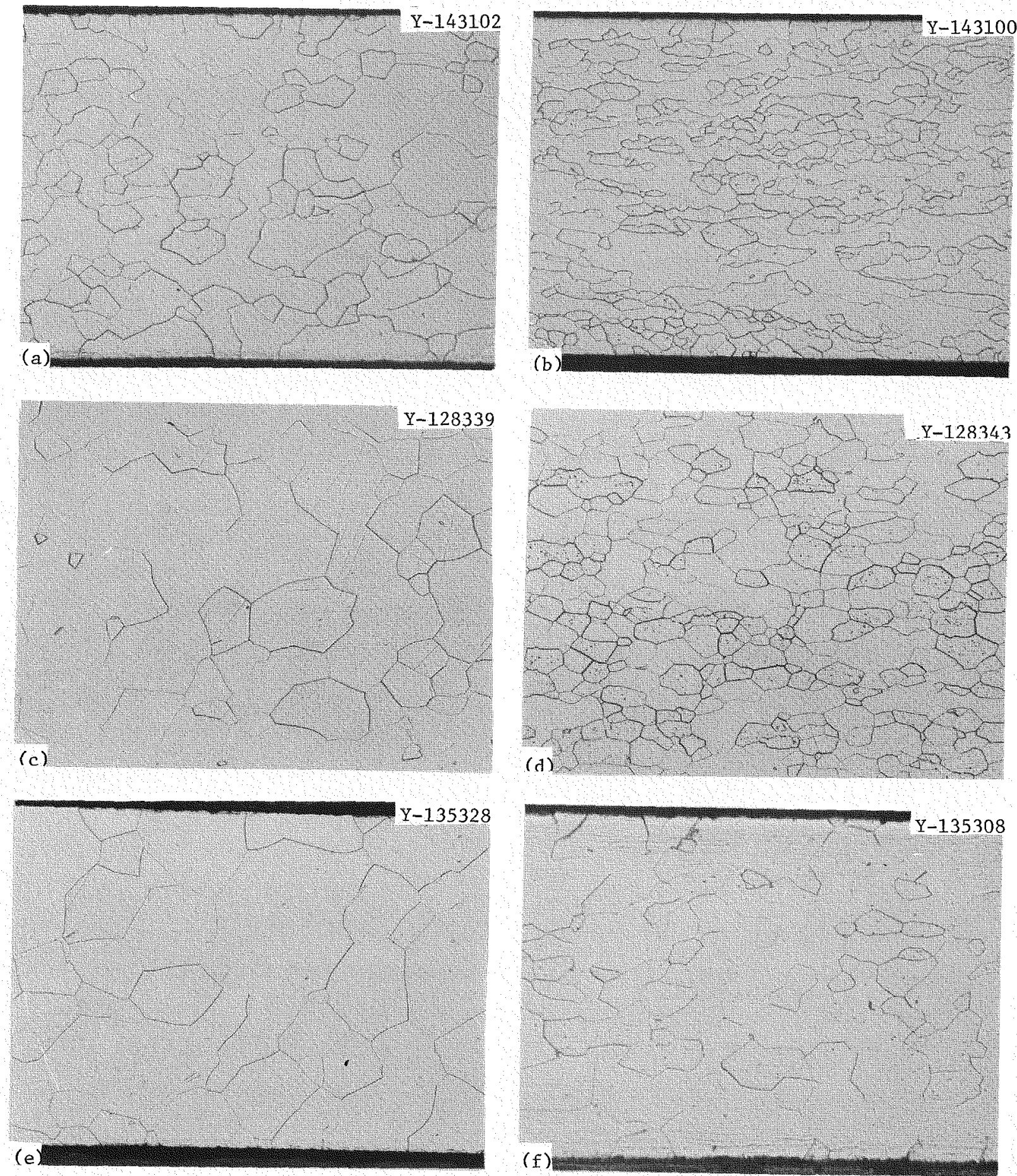

Fig. 4. Microstructures of Ir $0.3 \%$ W Alloys, $100 \times$. (a) WG and (b) DOP-4 specimens annealed $1 \mathrm{hr}$ at $1400^{\circ} \mathrm{C}$, (c) WG and (d) DOP-4 specimens annealed $1 \mathrm{hr}$ at $1500^{\circ} \mathrm{C}$, (e) WG and (f) DOP -4 specimens annealed $19 \mathrm{hr}$ at $1500^{\circ} \mathrm{C}$. Reduced $14 \%$. 

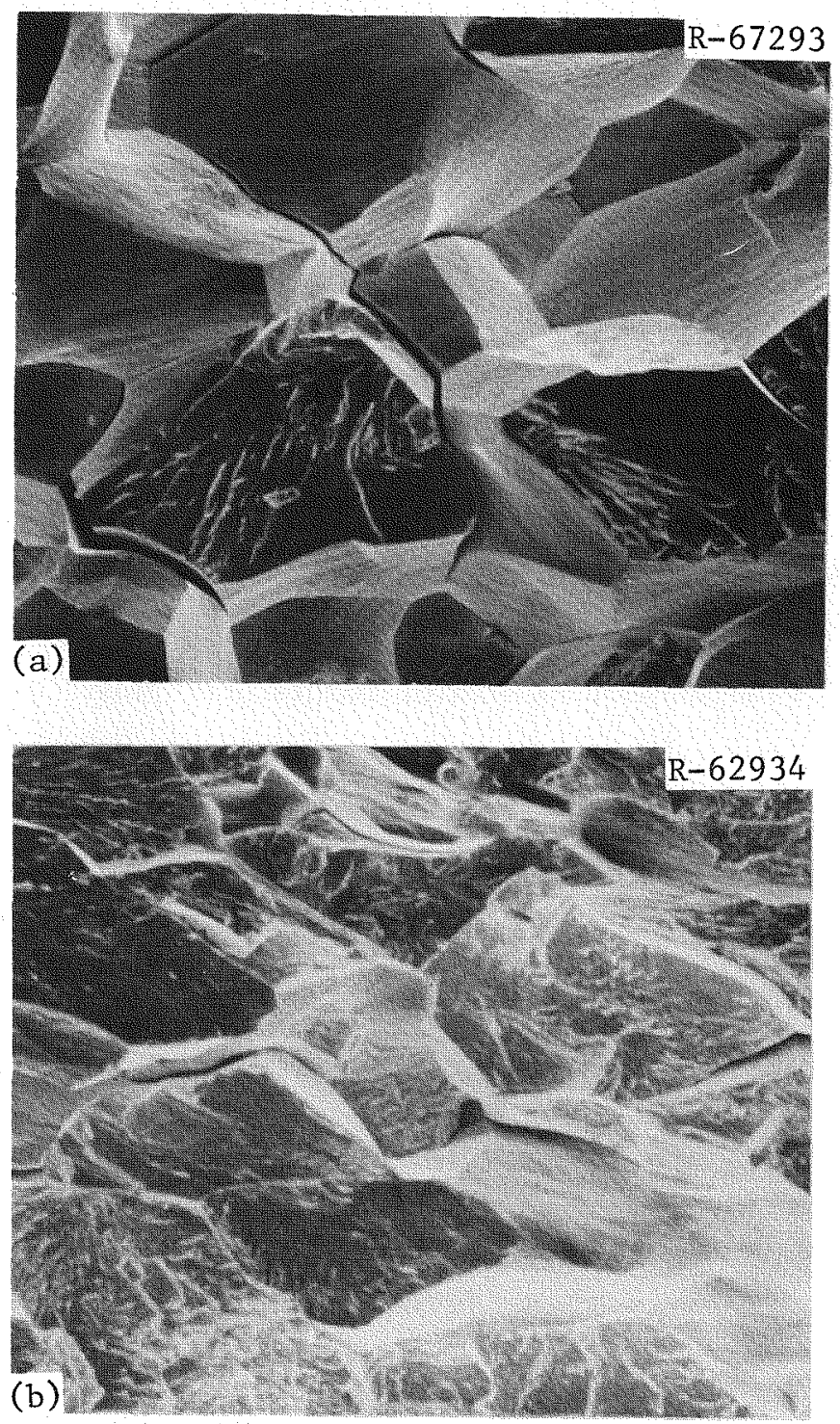

Fig, 5. Scanning Electron Microscope Fractograph of (a) Undoped WG (b) DOP -4 Tensile Specimens Fractured at $760^{\circ} \mathrm{C}, 300 \times$. 
CHARACTERIZATION OF IMPACT PROPERTIES OF DOP-4 AND UNDOPED (WG) ALLOYS

The containment materials for isotopic fuels must survive re-entry impact in case of an aborted space mission. To characterize these materials at high strain rates, equipment has been developed for impact testing at velocities to $300 \mathrm{fps}$ and tempertures to $1400^{\circ} \mathrm{C}$. The impact properties of $\operatorname{Ir}-0.3 \% \mathrm{~W}$, both $\mathrm{DOP}-4$ and undoped $\mathrm{WG}$, were determined as a function of impact velocity, test temperature, grain size, and longterm heat treatment.

\section{Impact Equipment}

The overall view of the equipment used for the uniaxial tensile impact test is shown in Fig. 6. The impact load is imparted to the specimen by an air-driven projectile. The impact equipment consists of four major parts: (1) a 7.62-cm-diam gas gun to accelerate the projectile and its carrier at velocities to $300 \mathrm{fps,}$ (2) impact chamber to test specimens in controlled atmosphere (such as argon or helium), (3) an induction heating system to heat specimens up to $1400^{\circ} \mathrm{C}$, and (4) a specimen rig to load specimens for impact test. The gas gun had been calibrated by various timing systems in the Isotopes Division of ORNL and the Process Equipment Company. ${ }^{11}$ A correlation ${ }^{12}$ exists between firing pressure and the kinetic energy of projectile and its carrier (Fig. 7), where

$$
\begin{aligned}
& p=\text { firing pressure, } \mathrm{psi} \\
& M=\text { weight of projectile and its carrier, } 1 \mathrm{~b} ; \text { and } \\
& V=\text { velocity of projectile and its carrier, fps. }
\end{aligned}
$$

Thus, the velocity of projectile can be determined from the firing pressure and the weight of the projectile and its carrier.

The specimens for the tensile impact test were loaded between two molybdenum alloy (TZM) pul1 rods and an end plate (Fig. 8). The

\footnotetext{
${ }^{11}$ Tipp City, Ohio.

${ }^{12}$ Information and data obtained from D. W. Ramey, Isotopes Division, Oak Ridge National Laboratory.
} 


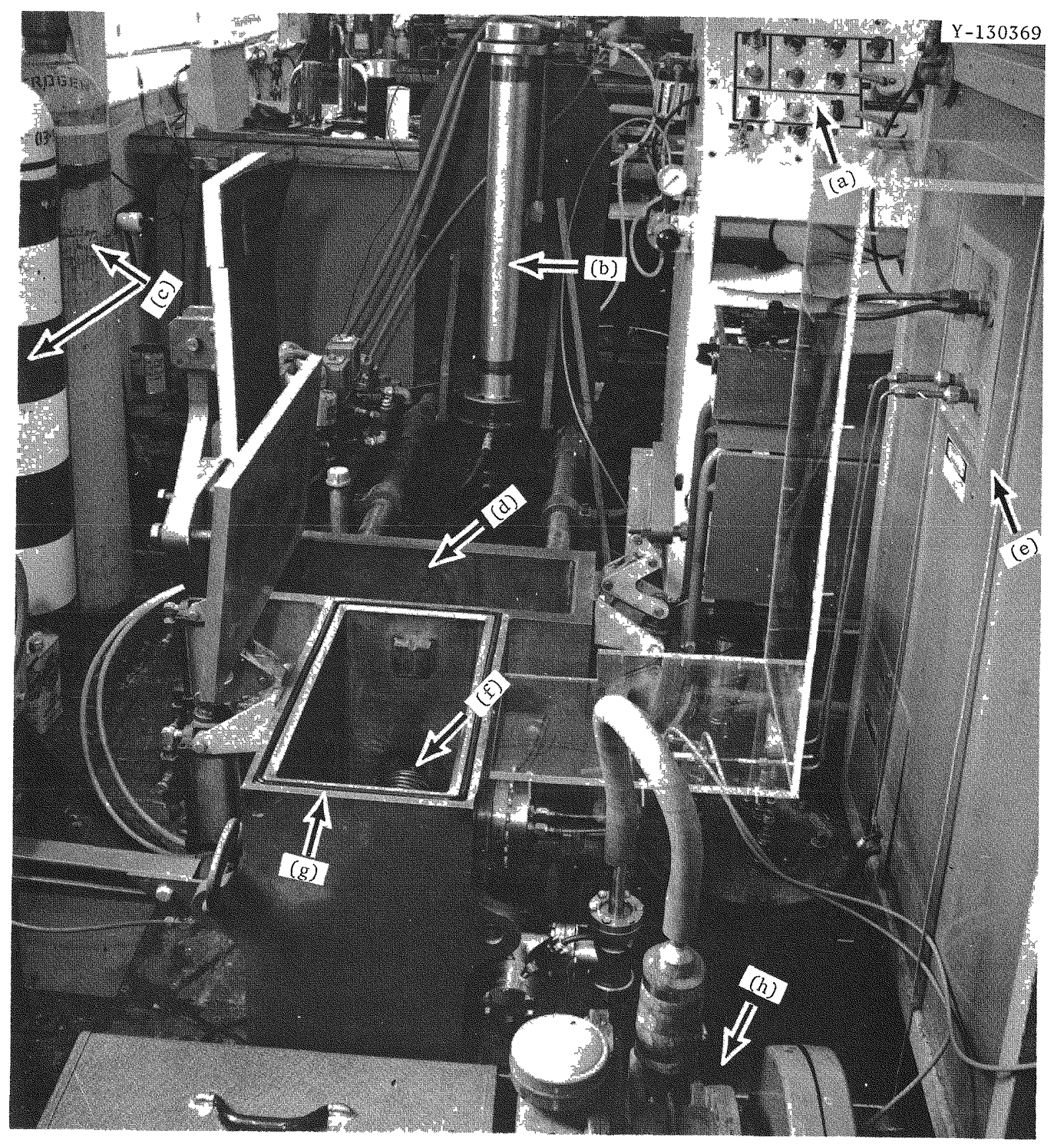

Fig, 6. High-Temperature Impact Test Equipment Used at ORNL, (a) Impact control console, (b) gas gun (in loading position) (c) gas tanks, (d) missile chamber, (e) induction unit, (f) induction coil, (g) impact chamber, and (h) mechanical pump. 


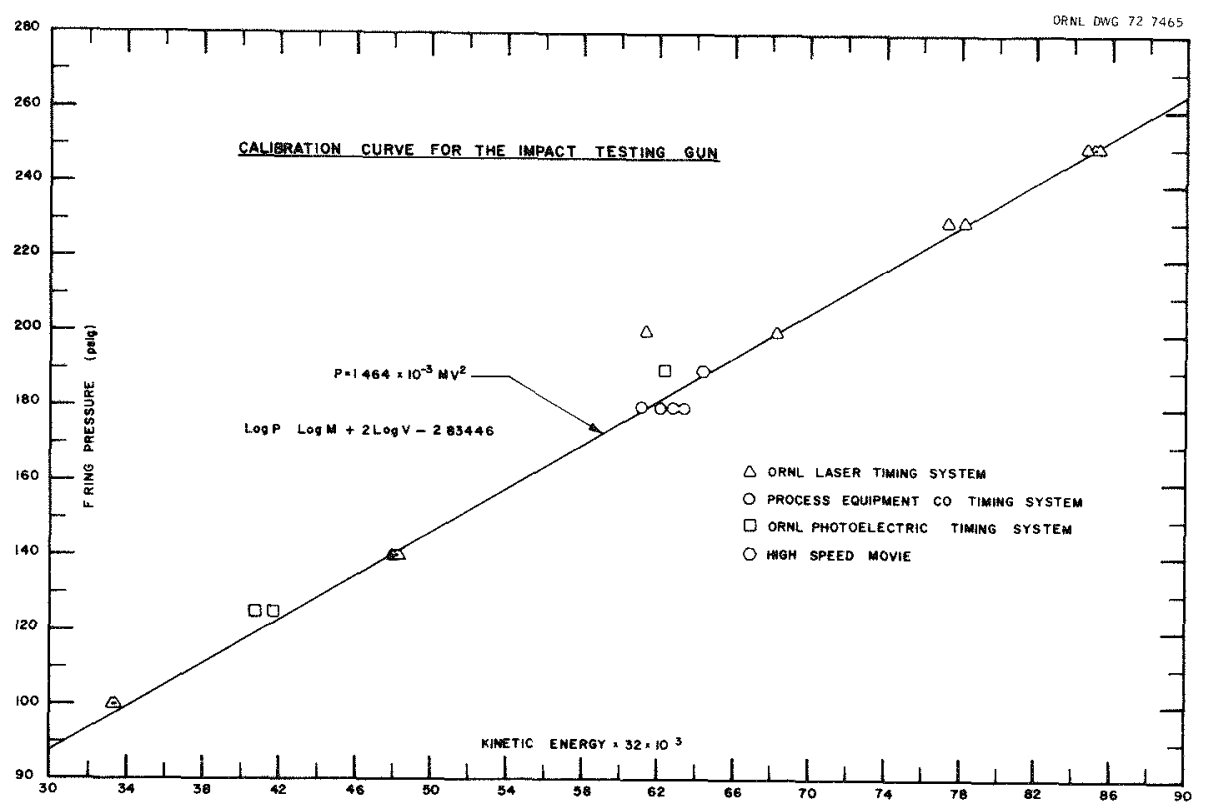

Fig. 7. Correlation Between Firing Pressure and Kinetic Energy of projectile and its carrier.

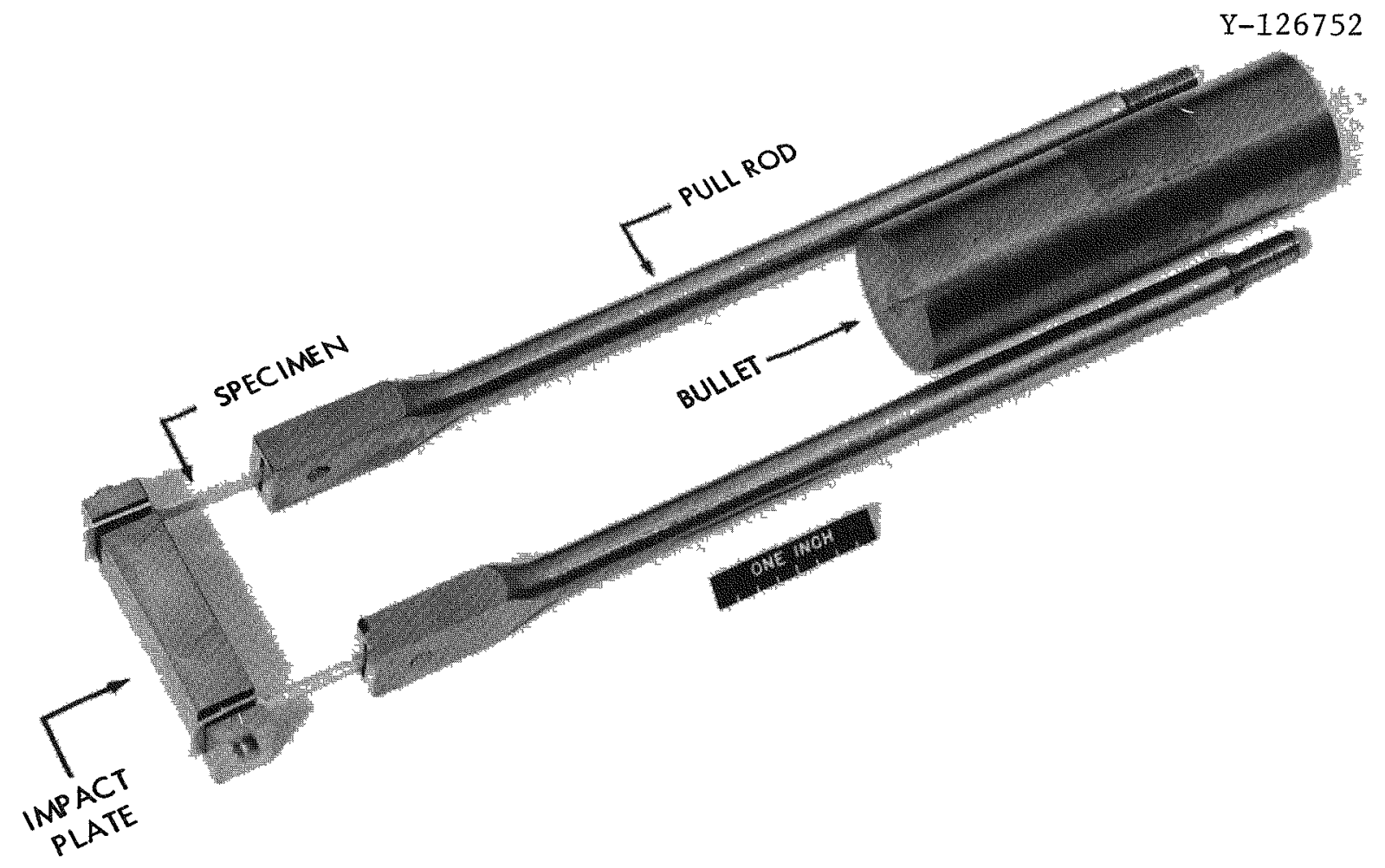

Fig. 8. Arrangement of Sheet Specimens for Tensile Impact Test. 
specimens were heated by radiation from an inductively heated tantalum susceptor, and the temperature was monitored by a pt vs Pt-10\% RH thermocouple centrally located on the specimen. When the specimens were heated to the desired temperature, the air-driven projectile was fired at a known velocity to break the specimens. The impact elongation and fracture mode were determined from an examination of the broken specimens.

\section{Impact Results}

The impact properties of DOP -4 and undoped (WG) $\operatorname{Ir}-0.3 \% \mathrm{~W}$ alloys were evaluated as a function of impact velocity, test temperature, grain size and heat treatment.

\section{Impact Velocity Effect}

DOP-4 and WG specimens were tested at various velocities to determine the effects of strain rate on their tensile impact properties. All the specimens were recrystallized for $1 \mathrm{hr}$ at $1500^{\circ} \mathrm{C}$, then impact tested at $1350^{\circ} \mathrm{C}$ (Table 7 and Fig. 9). Both alloys had about $45 \%$ uniform elongation and close to $100 \%$ reduction of area at a slow strain rate of $10^{-4} \mathrm{~m} / \mathrm{s}\left(3.3 \times 10^{-4} \mathrm{fps}\right)$. The tensile impact properties of undoped WG specimens depend strongly on test velocity (Fig. 9). The ductility of WG specimens decreases sharply with an increase in test velocity, and drops to around $10 \%$ elongation at about $90 \mathrm{~m} / \mathrm{s}$ (300 fps). By comparison, the impact properties of DOP-4 depend much less on velocity. DOP-4 specimens remained ductile and had $37 \%$ elongation and $90 \%$ reduction of area at $85 \mathrm{~m} / \mathrm{s}$ (280 fps).

The effect of test velocity on fracture behavior of $\operatorname{Ir}-0.3 \% \mathrm{~W}$ alloys is shown in Fig, 10 and Table 7. WG specimens exhibited ductile rupture with necking to a knife edge at the slow strain rate, but fractured by $T F$ without apparent necking at $30 \mathrm{~m} / \mathrm{s}(100 \mathrm{fps})$. The tendency for intergranular fracture increased with further increases in test velocity, and WG specimens fractured mainly by GBS at $85 \mathrm{~m} / \mathrm{s}$ (280 fps) (Fig, 10). The fracture morphology and low ductility of 
Table 7. Effect of Test Velocity on Tensile Impact Properties of DOP-4 and Undoped (WG)

Ir $-0.3 \% \mathrm{~W}$ Sheet Specimens ${ }^{a}$

Impact Tested at $1350^{\circ} \mathrm{C}$.

\begin{tabular}{lccc}
\hline $\begin{array}{l}\text { Test Velocity } \\
{[\mathrm{m} / \mathrm{s} \text { (fps) }]}\end{array}$ & $\begin{array}{c}\text { Elongation } \\
(\%)\end{array}$ & $\begin{array}{c}\text { Reduction } \\
\text { of Area } \\
(\%)\end{array}$ & Fracture Mode \\
\hline
\end{tabular}

WG Specimens

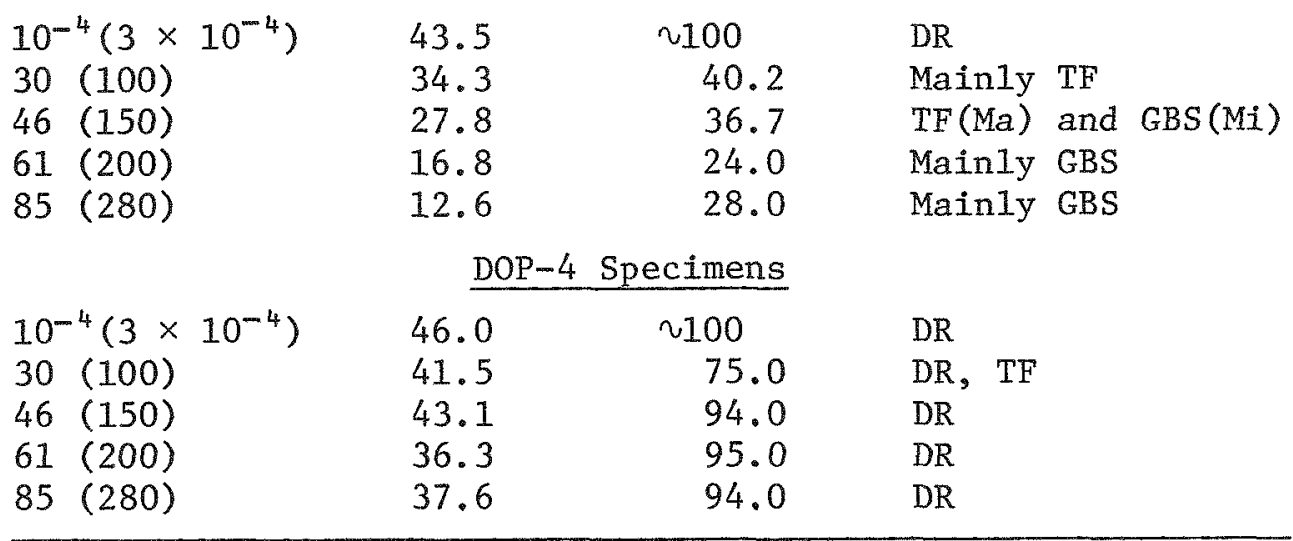

${ }^{\mathrm{a}}$ Specimens annealed $1 \mathrm{hr}$ at $1500^{\circ} \mathrm{C}$ before impact test.

$\mathrm{b}_{\mathrm{GBS}}=$ grain-boundary separation, $\mathrm{TF}=$ transgranular fracture, $\mathrm{DR}=$ ductile rupture, $\mathrm{Ma}=$ major fraction, and $\mathrm{Mi}=$ minor fraction.

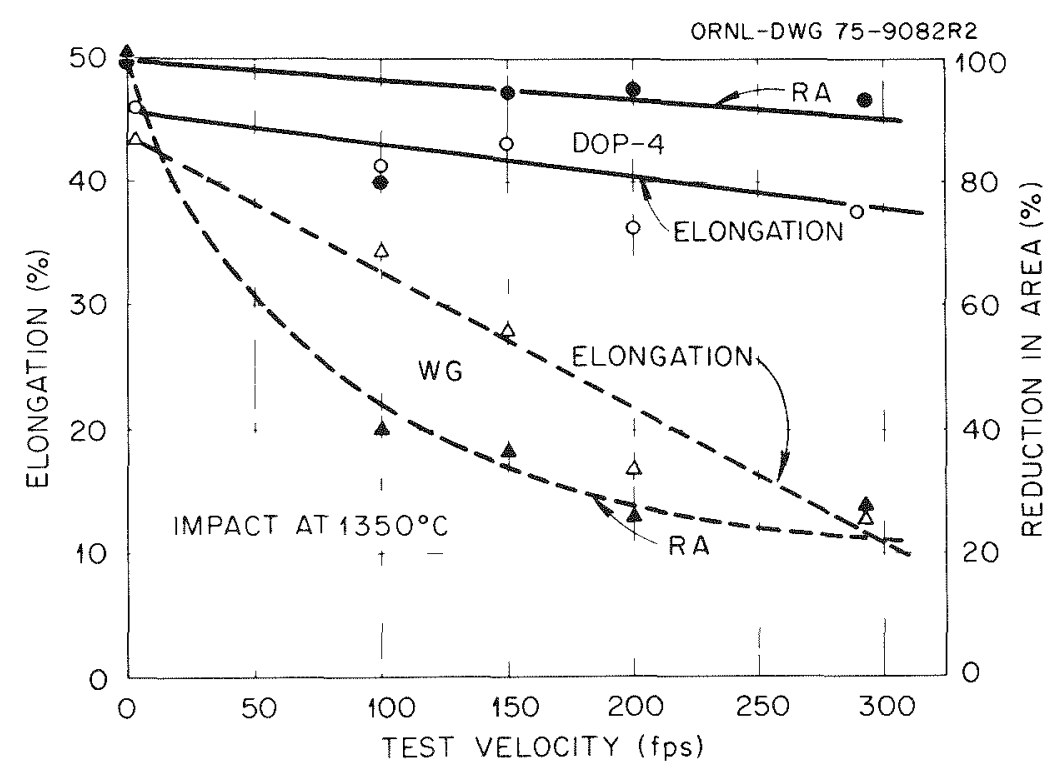

Fig. 9. Impact Elongation and Reduction in Area of DOP-4 and WG Specimens as a Function of Test Velocity. 

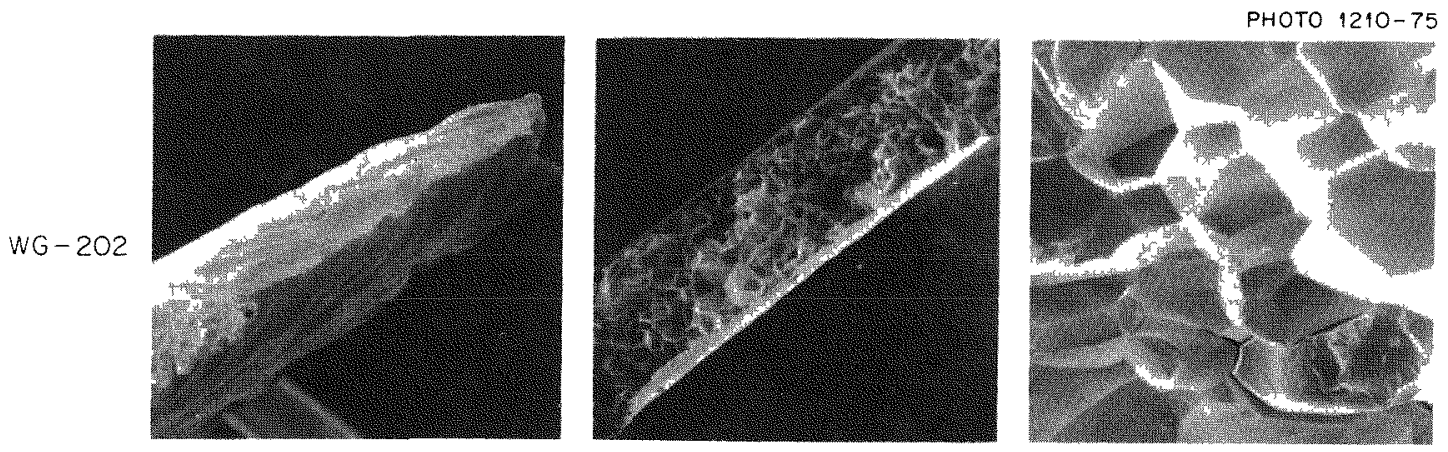

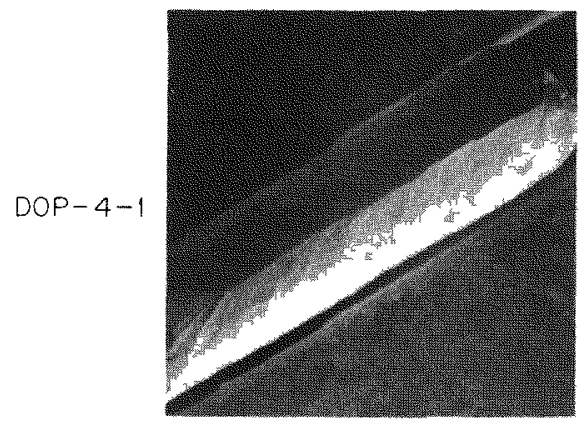

TENSILE TEST AT $1093^{\circ} \mathrm{C}$ AND $10^{4} \mathrm{fps}, 40 \mathrm{X}$

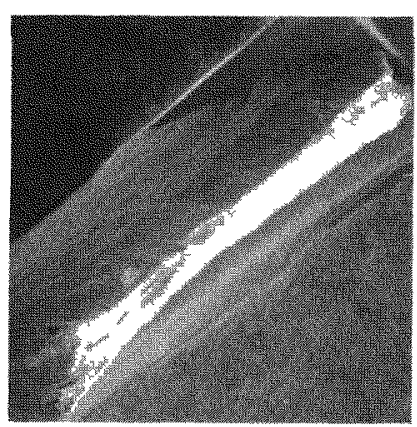

UNIAXIAL IMPACT AT $1350^{\circ} \mathrm{C}$ AND $280 \mathrm{fps}, 40 \mathrm{X}$

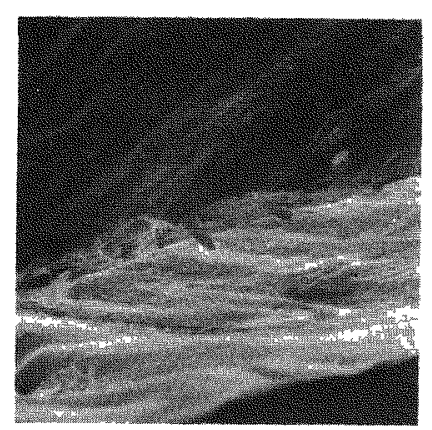

UNIAXIAL IMPACT AT $1350^{\circ} \mathrm{C}$ AND $280 \mathrm{fps}, 300 \mathrm{X}$

Fig. 10. Effect of Strain Rate on Fracture Mode of Undoped (WG-202) and Doped (DOP-4-1) Ir $-0.3 \% \mathrm{~W}$.

WG specimens tensile impact tested at $1350^{\circ} \mathrm{C}$ and $85 \mathrm{~m} / \mathrm{s}$ are similar to those observed on the Ir-0.3\% W PICS of FSA impact tested under the same conditions; therefore, there is no doubt that the brittle fracture associated with the impact of PICS is due to the high strain rate effect. DOP-4 specimens showed ductile rupture with a high reduction of area at all strain rates (Fig. 10). Thus, the DOP-4 alloy has much better impact resistance.

\section{Impact Temperature Effects}

WG and DOP -4 specimens were heat treated $1 \mathrm{hr}$ at $1500^{\circ} \mathrm{C}$, and impact tested in the range of $950-1350^{\circ} \mathrm{C}$ to determine the effects of temperature on impact properties. All the specimens were impacted at $85 \mathrm{~m} / \mathrm{s}$ (280 fps) (Table 8). Impact elongation is plotted as a function of test temperature (Fig. 11). The impact properties of WG and DOP-4 specimens are not sensitive to temperature above $1200^{\circ} \mathrm{C}$; however, below this temperature 
Table 8. Effect of Test Temperature on Tensile Impact Properties of DOP -4 and Undoped (WG) Ir-0.3\% W Sheet Specimens ${ }^{\mathrm{a}}$

Tested at $85 \mathrm{~m} / \mathrm{s}$ (280 fps)

\begin{tabular}{cccc}
$\begin{array}{c}\text { Temperature } \\
\left({ }^{\circ} \mathrm{C}\right)\end{array}$ & $\begin{array}{c}\text { Elongation } \\
(\%)\end{array}$ & $\begin{array}{c}\text { Reduction } \\
\text { of Area } \\
(\%)\end{array}$ & Fracture Mode \\
\hline
\end{tabular}

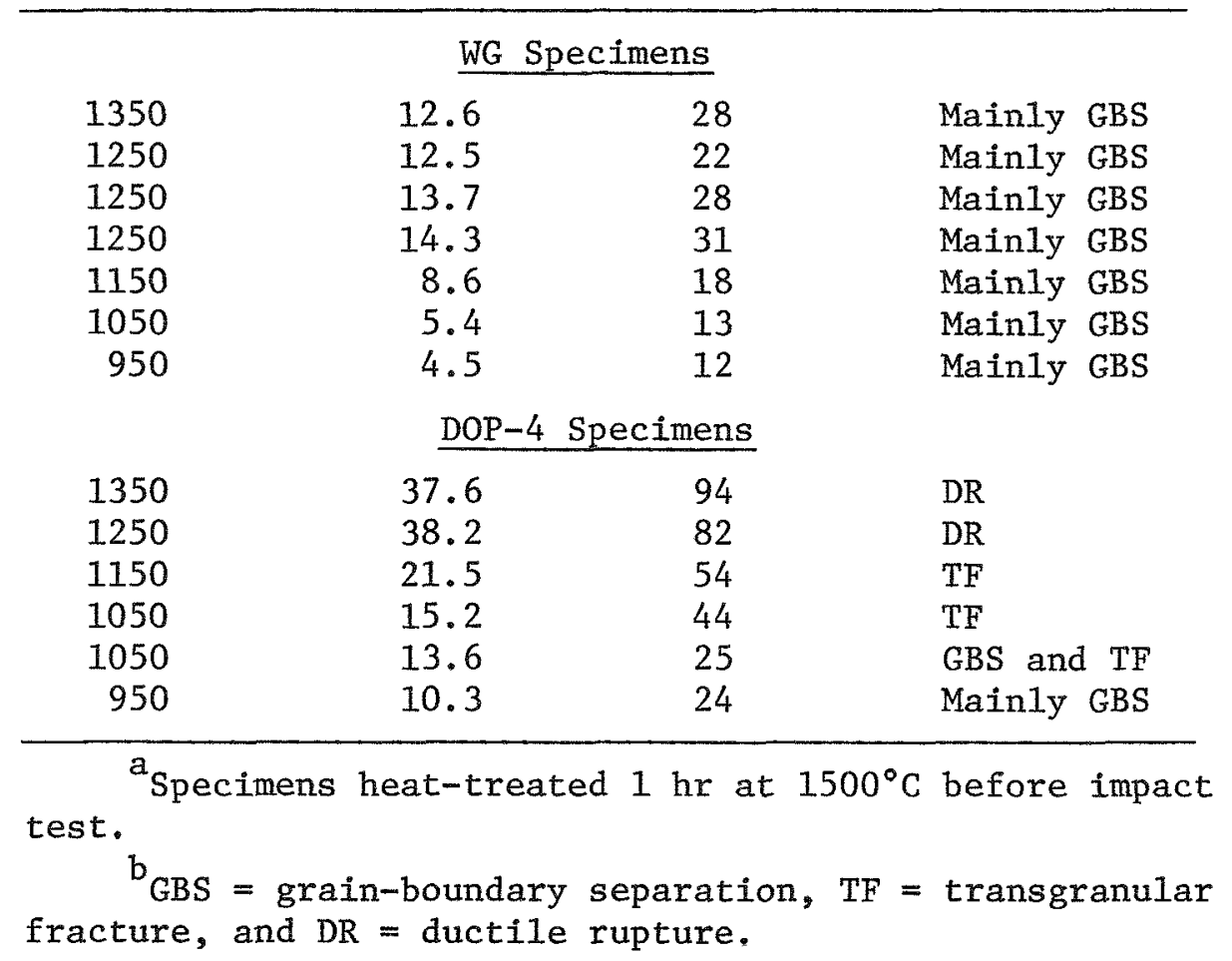

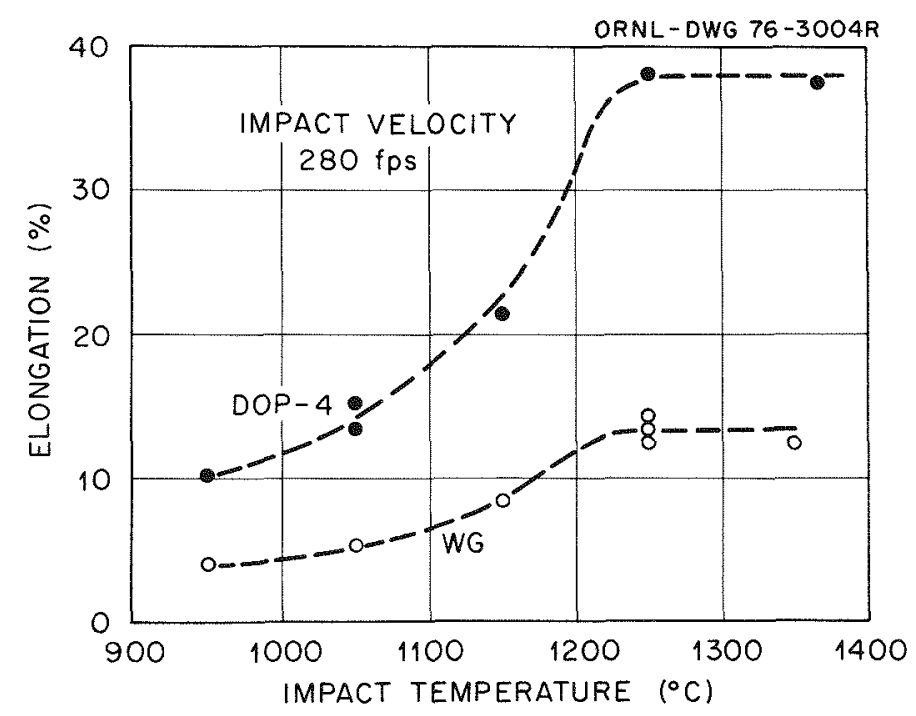

Fig. 11. Impact Elongation as a Function of Impact Temperature for DOP -4 and Undoped (WG) Ir $-0.3 \% \mathrm{~W}$ Alloys. 
the ductility decreases for both alloys. DOP -4 was much more ductile than WG at all temperatures. The WG specimens fractured mainly by GBS at these temperatures, while the fracture mode of DOP-4 changed from ductile rupture above $1200^{\circ} \mathrm{C}$ to mixed $\mathrm{GBS}$ and $\mathrm{TF}$ at $1050^{\circ} \mathrm{C}$ and to mainly $\mathrm{GBS}$ at $950^{\circ} \mathrm{C}$.

\section{Grain Size Effect}

The impact properties of DOP-4 and WG may be given as a function of grain size produced by short-term heat treatments between $1300-1800^{\circ} \mathrm{C}$ (Table 9 and Fig. 12). A11 the specimens were impact tested under the same conditions, for example, $85 \mathrm{~m} / \mathrm{s}$ (280 fps) and $1350^{\circ} \mathrm{C}$. The impact elongation of WG specimens decreases continuous1y with increasing grain size, and reduces to about $4 \%$ with 2 or 3 grains across the specimen. The ductility of DOP-4 is not sensitive to grain size in the fine grain size range, but the ductility decreases in the coarse grain size range. At a given grain size, the impact ductility of DOP-4 is much better than for the WG specimens. This strongly suggests the possible improvement of grain boundary strength in DOP-4 alloy through segregation of dopants at the boundaries.

Table 9. Effect of Grain Size on Tensile Impact Properties of DOP-4 and Undoped (WG) Ir $-0.3 \% \mathrm{~W}$ Sheet Specimens Tested at $85 \mathrm{~m} / \mathrm{s}(280 \mathrm{fps})$ and $1350^{\circ} \mathrm{C}$

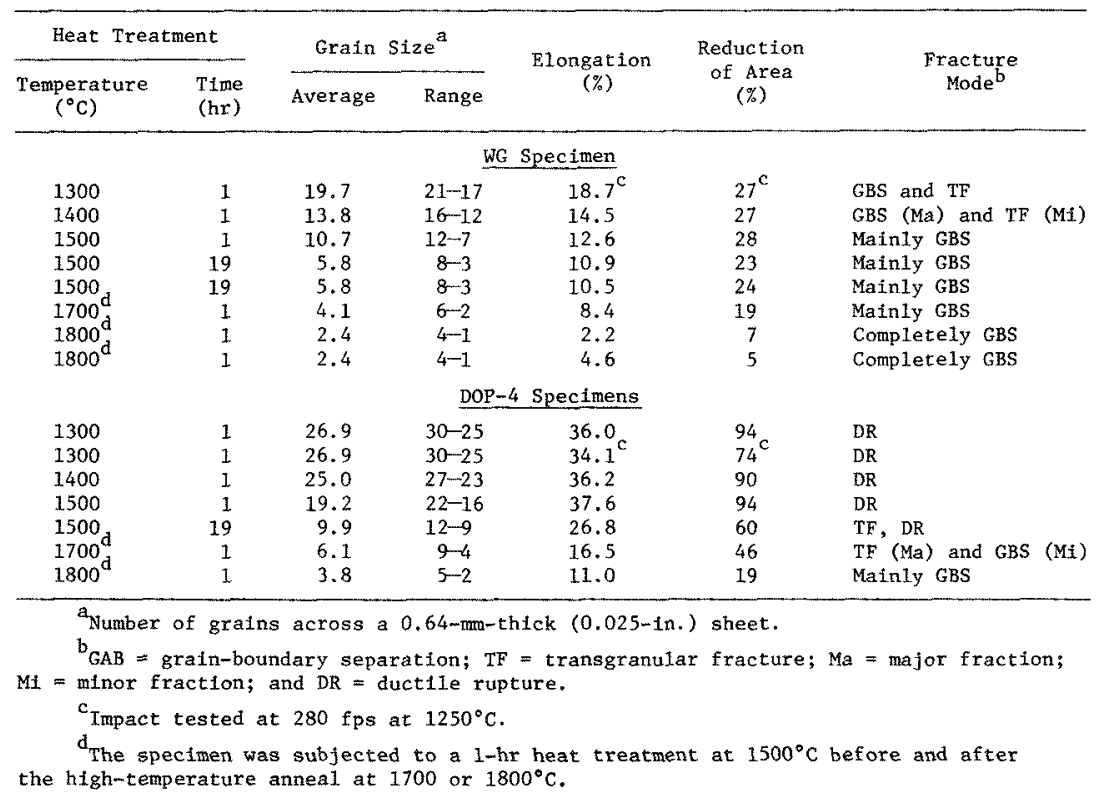




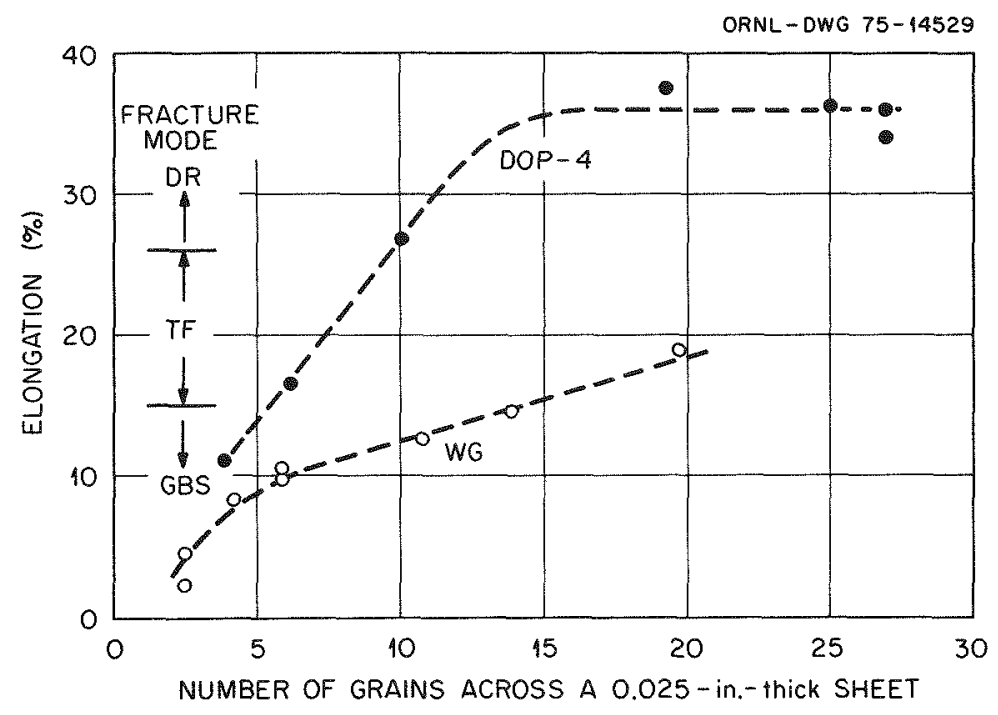

Fig. 12. Impact Elongation and Fracture Mode as a Function of Grain Size for DOP -4 and Undoped (WG) Ir $-0.3 \%$ W Alloys.

Both DOP -4 and WG alloys may lose their ductility when the grain size is sufficiently large since both ductility curves may extend to the origin (Fig. 12). This seems to agree well with the biaxialimpact data obtained ${ }^{13}$ recently at LASL. Thus, it is the grain size, rather than grain-boundary chemistry that controls the impact properties of $\mathrm{Ir}-0.3 \% \mathrm{~W}$ alloys in the coarse grain size range. Since the dopant additions also retard grain growth, the combined effects result in the DOP-4 alloy having an impact ductility a factor of 2 to 3 higher than for the undoped alloy for any annealing condition.

The specimens with more than $25 \%$ elongation generally fractured by ductile rupture, while those specimens with less than $15 \%$ elongation fractured by GBS. Between these limits, the fracture mode was predominantly by $\mathrm{TF}$.

\section{Long-Term Anneal Effect}

DOP -4 and WG specimens were annealed to $2000 \mathrm{hr}$ to $1330^{\circ} \mathrm{C}$, the MHW fue1-clad temperature, and then impact tested at $1350^{\circ} \mathrm{C}$ and $85 \mathrm{~m} / \mathrm{s}$ (280 fps) (Table 10 and Fig. 13).

${ }^{13}$ Private communications with Sig. Hecker, LASL, 1975-1976. 
Table 10. Effect of Long-Term Anneal at $1330^{\circ} \mathrm{C}$ on the Impact Properties of DOP -4 and Undoped (WG) $\mathrm{Ir}-0.3 \% \mathrm{~W}$ Sheet

Specimens Impacted at $85 \mathrm{~m} / \mathrm{s}$ (280 fps) and $1350^{\circ} \mathrm{C}$

\begin{tabular}{|c|c|c|c|c|c|}
\hline $\begin{array}{c}\text { Annealing } \\
\text { Time } \\
\text { (hr) }\end{array}$ & Specimen & $\begin{array}{l}\text { Grain } \\
\text { Size }\end{array}$ & $\begin{array}{c}\text { Impact } \\
\text { Elongation } \\
(\%)\end{array}$ & $\begin{array}{c}\text { Reduction } \\
\text { of Area } \\
(\%)\end{array}$ & $\begin{array}{l}\text { Fracture } \\
\text { Mode }^{b}\end{array}$ \\
\hline $1^{c}$ & WG & 19.7 & 18.7 & 27 & GBS and TF \\
\hline $1^{c}$ & DOP -4 & 26.9 & 36.0 & 94 & DR \\
\hline 200 & WG & 9.0 & 13.7 & 28 & Mainly GBS \\
\hline 200 & $\mathrm{DOP}-4$ & & & & \\
\hline 480 & WG & 8.3 & 8.4 & 24 & Mainly GBS \\
\hline 480 & DOP -4 & 15.2 & 26.5 & 9.0 & $\mathrm{DR}$ \\
\hline 980 & WG & 7.3 & 8.6 & 20 & Mainly GBS \\
\hline 980 & DOP -4 & 11.0 & 27.2 & 88 & $\mathrm{DR}$ \\
\hline 2000 & WG & 4.7 & 7.8 & 19 & Mainly GBS \\
\hline 2000 & DOP -4 & 8.5 & 24.0 & 61 & Mainly $\mathrm{TF}$ \\
\hline
\end{tabular}

a Number of grains across a 0.64 -mm-thick (0.025-in.) sheet.

$\mathrm{b}_{\mathrm{GBS}}=$ grain boundary separation, $\mathrm{TF}=$ transgranular fracture, and $\mathrm{DR}=$ ductile rupture.

${ }^{\mathrm{c}}$ Anneal $1 \mathrm{hr}$ at $1300^{\circ} \mathrm{C}$.

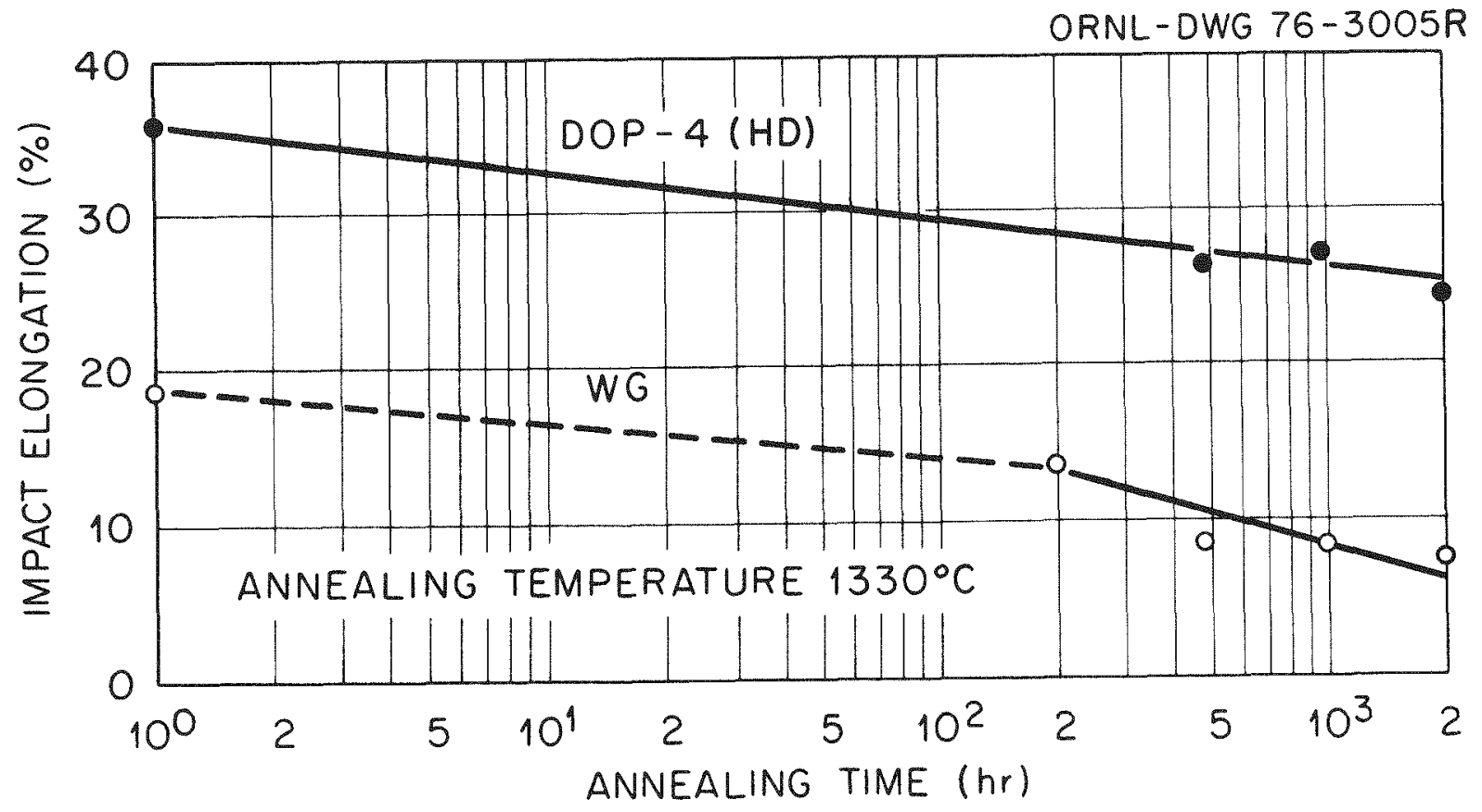

Fig. 13. Effect of Long-Term Annealing at $1330^{\circ} \mathrm{C}$ on Impact Elongation of WG and DOP-4, Ir $-0,3 \%$ W Alloys. 
The grain size of the specimens was also measured (Table 10). The impact elongation of both alloys decreases with annealing time, and this decrease is apparently due to grain growth. The WG material had a marginal ductility of $15 \%$ elongation after being annealed for only $30 \mathrm{hr}$ at $1300^{\circ} \mathrm{C}$, while DOP -4 material remains ductile after annealing for $2000 \mathrm{hr}$. Thus, DOP-4 material is much more resistant to degredation due to long-term heat treatment at $1330^{\circ} \mathrm{C}$. A detailed study of grain-growth behavior in doped and undoped $\operatorname{Ir}-0.3 \% \mathrm{~W}$ alloys has been reported. ${ }^{14}$

Results (Tables 7-10 and Figs. 9-13) indicate the impact properties of DOP $-4 \mathrm{Ir}-0.3 \% \mathrm{~W}$ alloy are far superior to those of the undoped a11oy.

Correlation of Uniaxial Tensile Impact Test with MHW/FSA Impact Test

Postimpact containment shells (PICS) were made from DOP-4 material to confirm the superior impact properties in actual hardware configurations. Blanks from DOP $-4-1$ to -4 sheets were fabricated into hemishells and assembled with a $76 \%$ dense $\mathrm{ThO}_{2}$ (fuel simulant) and then encased in a 10-mm-thick GIS at Monsanto Research Corporation (MRC) and GE. The hemishells were heat treated for $16.5 \mathrm{hr}$ at $1500^{\circ} \mathrm{C}$ before welding into the postimpact sphere assembly. The three FSA, designated as MHT-90, -91 , and -92 , were impact tested against a granite target at $1370^{\circ} \mathrm{C}$ at a velocity of $90-95 \mathrm{~m} / \mathrm{s}(295-304 \mathrm{fps})$. Table 11 lists the impact parameters and the postimpact results obtained at $G E$, and the grain-size measurement at ORNL. A detailed metallographic examination of these three impact tested FSA has been reported recently. 15

Al1 three DOP-4 PICS survived the MHW/FSA impact with no indication of breaching or cracking. Figure 14 (b) shows the impact face of MHT-91. The normal deformation at the region of maximum hoop strain ranged between 9.3 and $11.2 \%$. Figure 14 (a) shows the impact face of a WG

\footnotetext{
${ }^{14}$ D. E. Harasyn and A. C. Schaffhouser, Grain Growth in Ir-0.3\% W AZZoys, ORNL-5233 (January 1977).

${ }^{15}$ E. M. Cramer and S. S. Heckler, Postimpact Examinations of the Dop-4 Ir Shelzs from Simulant Fuel Sphere Assemblies, LA-6176-MS, LASL, (February 1976).
} 
Table 11. FSA Impact Data ${ }^{a}$ for DOP -4 Ir $-0.3 \%$ W Alloy

\begin{tabular}{|c|c|c|c|}
\hline & MHT-90 & MHT-91 & MHT-92 \\
\hline \multicolumn{4}{|l|}{ PICS Identity } \\
\hline Female & DOP $-4-3$ & DOP $-4-2$ & DOP $-4-4$ \\
\hline Male & DOP $-4-1$ & DOP $-4-2$ & DOP $-4-4$ \\
\hline \multicolumn{4}{|l|}{ Impact Condition } \\
\hline Temperature, ${ }^{\circ} \mathrm{C}$ & 1370 & 1370 & 1370 \\
\hline Rotation, degrees from normal hit & 50 & 4 & 48 \\
\hline Velocity, $\mathrm{m} / \mathrm{s}$ & 95 & 90 & 89.6 \\
\hline Heat Treatment at $1500^{\circ} \mathrm{C}$, hr & 16.5 & 16.5 & 16.5 \\
\hline \multicolumn{4}{|l|}{ Post Impact Results } \\
\hline Average diameter, $\mathrm{mm}$ & 44.50 & 44.68 & 45.34 \\
\hline Average height, mm & & 28.75 & 28.58 \\
\hline Average deformation, $\mathrm{mm}$ & 9.3 & 9.6 & 11.2 \\
\hline Dye penetration examination & negative & negative & negative \\
\hline $30 \mathrm{X}$ examination & negative & negative & negative \\
\hline Grain Size Measurement ${ }^{c}$ & 11.4 & 10.8 & 11.1 \\
\hline
\end{tabular}

${ }^{a}$ Data obtained from General Electric Company, except for the grain size measurement.

$b_{\text {Microcracking in regions having dye penetrant indications before }}$ impact; no other cracking at $30 \mathrm{x}$ or by dye penetrant.

${ }^{C}$ Number of grains per thickness; measured at ORNL. 

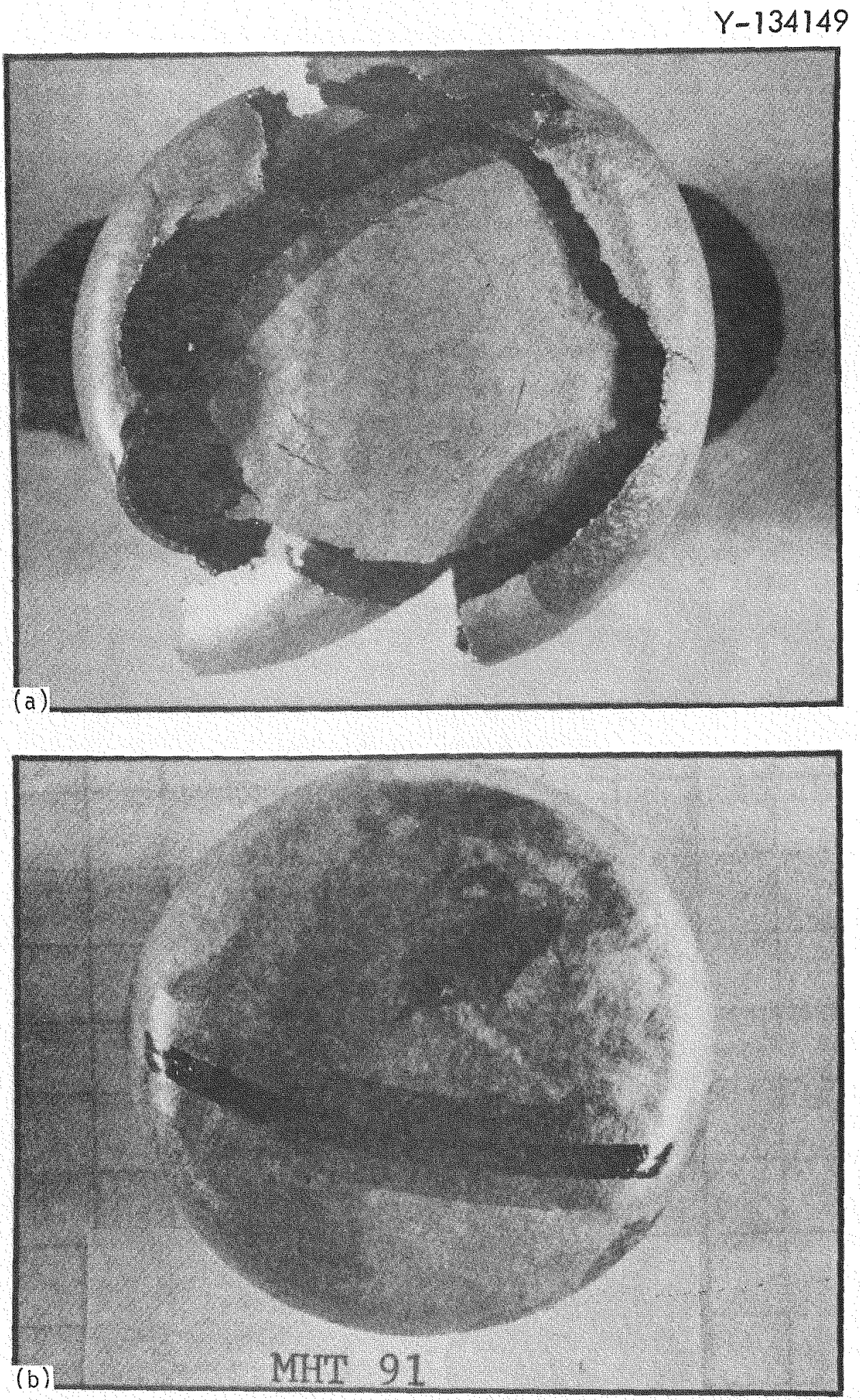

Fig. 14. Impact Face of FSA $/$ MHW Impact Tested at $1370^{\circ} \mathrm{C}$ and $90 \mathrm{~m} / \mathrm{s}$. (a) Undoped WG material (MHT-94); (b) DOP-4 material (MHT-91). 
Ir-0.3\% W FSA under similar conditions. Fingerprint cracks and hoopstrain fallure seen after tests of some undoped Ir $0.3 \% \mathrm{~W} \mathrm{FSA}$ were not evident in these DOP-4 tests. A total of 4 WG FSA were impact tested; all of which failed with different degrees of breaching. This comparision confirms our uniaxial tensile impact data that the impact performance of DOP-4 material is far superior to that of the undoped material. Therefore, the development of the DOP-4 alloy greatly increases the safety margin of the MHW heat sources whose next mission is a space probe to Jupiter and Saturn in 1977.

The MHW/FSA impact test is expensive and time-consuming. In addition, it is a multicomponent test and variations in fuel and GIS properties or other interactions may influence the behavior of this iridium. The uniaxial impact test would serve as a quick and useful method to predict the outcome of the MHW/FSA impact test if a suitable correlation could be established between the two tests.

An effort was made to correlate the impact ductilities with grain size of materials from the tests. Before the FSA impact test, the $\mathrm{Ir}-0.3 \% \mathrm{~W}$ PICS were heat treated 16 to $19 \mathrm{hr}$ at $1500^{\circ} \mathrm{C}$. This heat treatment is necessary to simulate the grain growth in a period of ground operation. This heat treatment produced about 9-13 grains across the PICS thickness [Figs, 15 and 4(f)]. The DOP-4 specimen with that grain size had more than $25 \%$ impact elongation (Fig. 12) and fractured by ductile rupture when impact tested at $1350^{\circ} \mathrm{C}$ and $85 \mathrm{~m} / \mathrm{s}$. The success in the DOP-4 sphere impact tests at GE suggests that $25 \%$ impact elongation is sufficient for cladding materials to survive the FSA/MHW impact. The FSA heat treatment produced 5-7 grains across the PICS of WG material [Fig. 4(e)]. The impact test results (Fig. 12) indicate that the undoped Ir-0.3\% W with that grain size had about 9-12\% elongation and its fracture mode was mainly GBS. The failures in the WG FSA impact tests suggest that more than $12 \%$ impact ductility is needed for surviving these tests. On the FSA impact test, the nominal deformation at the hoop strain region usually ranges between $8-12 \%$ but sometimes may reach as high as $14-15 \%$. Thus, this comparison, indicates that cladding materials should have $15 \%$ or more ductility in order to ensure success in the MHW/FSA impact test. 


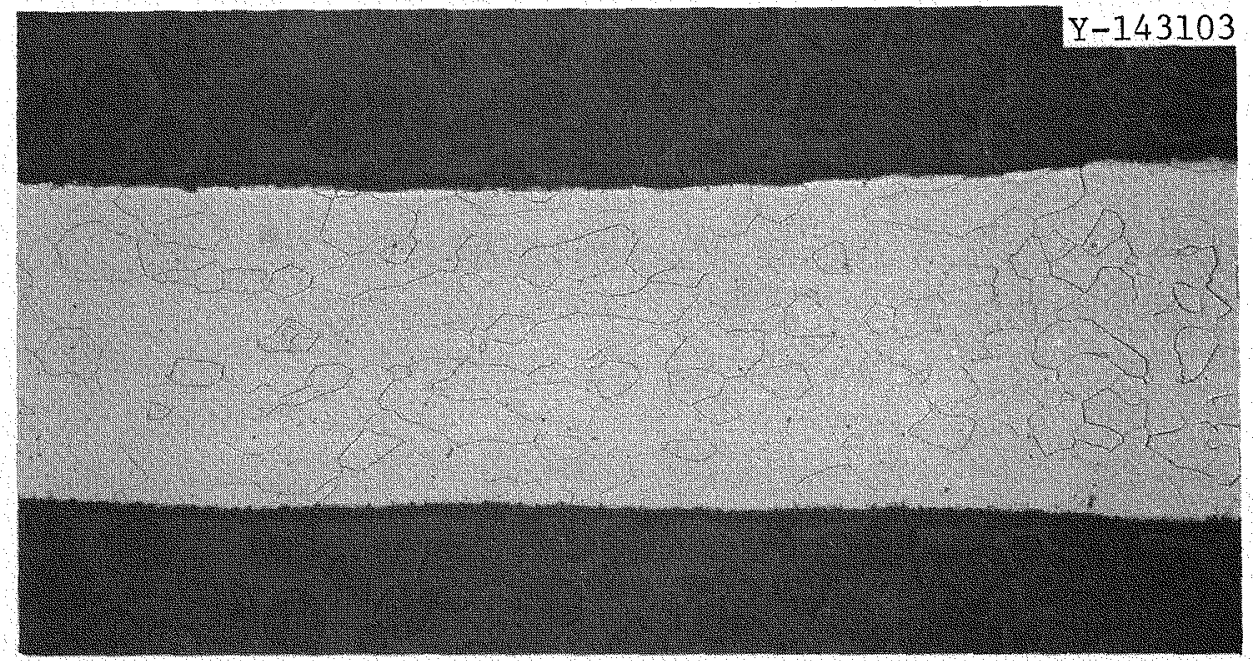
MHT-92, $50 \times$.

Fig. 15. Microstructure of DOP -4 Ir $0.3 \%$ W PICS sectioned from GENERAL DISCUSSION

Function of DOP-4 Dopants

The results presented in the previous sections indicate that the total of $240 \mathrm{ppm} \mathrm{DOP}-4$ dopants ( $30 \mathrm{ppm} \mathrm{Th,} 40 \mathrm{Al}, 80 \mathrm{Fe}, 16 \mathrm{Ni}$, and $75 \mathrm{Rh}$ ) added to the DOP-4 alloy suppresses the brittle grain-boundary fracture and greatly improves the impact properties of $\mathrm{Ir}-0.3 \% \mathrm{~W}$. In addition, the DOP -4 dopants raise the recrystallization temperature of $\operatorname{Ir}-0.3 \% \mathrm{~W}$ and retard its grain growth at high temperatures. Evidence obtained so far suggests that the DOP -4 dopants affect the metallurgical and mechanical properties of Ir $-0.3 \% \mathrm{~W}$ through segregation of the dopants to grain boundaries, and precipitation of second-phase particles.

\section{Segregation of the Dopants to Grain Boundaries}

Chemical analyses of the intergranularly-fractured surfaces by SSMS have Indicated ${ }^{16}$ that thorium tends to segregate strongly near the grain boundaries of iridium and Ir $0.3 \% \mathrm{~W}$ alloys. The thorium

${ }^{16} \mathrm{C} . \mathrm{T}$. Liu and $\mathrm{H}$. Inouye, Study of Iridium and Iridium-Tungsten AlZoys for Space Radioisotopic Heat Sources, ORNL-5240 (December 1976). 
concentration in the vacinity of the boundaries is higher than its bulk value by four orders of magnitude. SSMS analysis has also shown that aluminum iron tend to segregate near the grain boundaries, but not as strongly as thorium. The segregation of thorium to the grain boundaries has been confirmed by auger electron spectroscopy (AES). White and Clausing ${ }^{17}$ at ORNL have found that the thorium concentration at the grain boundary of the DOP -4 material is of the order of 3-5 at. \%, as compared with only $30 \mathrm{ppm}$ (by wt) in the bulk. Inert-ion sputtering at the fracture surface indicates that the thorium is concentrated only within a few atom layers ( $<10$ atm layers) of the grain boundary. Similar AES studies at LASL have shown ${ }^{18}$ about the same amount of thorium segregation at the grain boundary of the DOP-4 alloy. No thorium is detected at the grain boundary of undoped (WG) specimens.

The exact role played by dopants at the grain boundary is not yet clear; however, their presence improves the coherent strength of the boundary. As a consequence, the DOP-4 material is more resistant to grain-boundary fracture and has superior impact properties. The impact properties of the DOP-4 and undoped alloys will be discussed in detail later.

\section{Precipitation of Second-Phase Particles}

Small amounts of second-phase particles appear in the DOP-4 specimens but not in the undoped specimens (Fig. 4). Since the solubility of $\mathrm{Fe}, \mathrm{Ni}$ and $\mathrm{Rh}$ in iridium is quite high, the second-phase particles are most probably an iridium compound containing thorium and possibily aluminum. The published iridium-thorium phase diagram indicates $^{19}$ only very limited solubility of thorium in iridium and the first compound formed at the iridium-rich end is $\operatorname{ThIr}_{5}$. Numerous precipitates probably $\operatorname{ThIr}_{5}$, are clearly visible ${ }^{20}$ in the $\operatorname{Ir}-0.3 \% \mathrm{~W}$ alloys

${ }^{17}$ Private communication with C. L. White and R. E. Clausing, 1975.

${ }^{18}$ R. D. Baker, Los Alamos Scientific Laboratory., private communications during 1974-1976.

${ }^{19} \mathrm{~F}$. A. Shunk, "Ir-Ti He Iridium-Titanium" p. 466, Constitution of Binary AZZoys, Second Supplement, McGraw-Hill Book Company, N.Y., 1969.

${ }^{20} \mathrm{C}$. T. Liu and $\mathrm{H}$. Inouye, unpublished results. 
containing high levels of thorium. The particles in DOP-4 seem to be stable and do not grow appreciably on heat treatment at $1500^{\circ} \mathrm{C}$ (Fig. 4).

The DOP-4 specimens distinctly show an elongated grain structure on short-term heat treatments at $1500^{\circ} \mathrm{C}$ or below (Fig. 4). The elongated structure probably results from the restriction of grain growth by the particles which line up along the fibrous direction during hot fabrication. The grains in the DOP-4 specimens become equiaxed after being annealed $19 \mathrm{hr}$ at $1500^{\circ} \mathrm{C}$ [Fig. 4(f)]; however, the grain size is still much finer than that of the undoped alloy. Probably the slower grain growth in the DOP-4 alloy is due to both particle and impurity atom pinning at the grain boundary. As noted previously, a small grain size is one of the factors that contributes to the better impact properties of the DOP -4 alloy.

\section{Effects of Grain Size, Dopant Addition, Impact Velocity and Test Temperature on Impact Properties}

The tensile and impact data in the previous sections indicate that the deformation and fracture behavior of $\operatorname{Ir}-0.3 \% \mathrm{~W}$ is sensitive to grain size, dopants, impact velocity and test temperature. The brittle fracture associated with GBS in these materials is promoted with decreasing test temperature and increasing strain rate or grain size. A11 these results can be correlated on the basis of the stress concentration on grain boundaries through a model of pile up of glide dislocations. The stress concentration due to pile up of dislocations ${ }^{21}$ is

$$
\left[\sigma-\sigma_{0}\right][d / s]^{1 / 2}
$$

where $\sigma$ is the applied stress, $\sigma_{0}$ the frictional stress against the motion of dislocations on the slip plane, $d$ the grain diameter, and $s$ a distance beyond the tip of a pile up.

${ }^{21}$ J. D. Eshelby, F. C. Frank, and F.R.N. Nabarro, "Equilibrium of Linear Arrays of Dislocations," Philos. Mag. 42: 351 (1951). 
Intergranular fracture will occur if the stress concentration at a grain boundary reaches the coherent strength of the boundary $\sigma_{c}$ :

$$
\left(\sigma_{f}-\sigma_{0}\right)(d / s)^{1 / 2}=\sigma_{c}
$$

where $\sigma_{f}$ is the fracture stress. To correlate the stress with strain, $\varepsilon$, the Ludwik-type equation ${ }^{22}$ is used:

$$
\sigma=\sigma_{i}+K \varepsilon^{n}
$$

where $\sigma_{i}, K$ and $n$ are material constants. At fracture,

$$
\sigma_{f}=\sigma_{i}+K \varepsilon_{f}^{n}
$$

where $\varepsilon_{f}$ is the fracture strain. Combination of Eqs. (1) and (3) and rearrangement gives the final expression:

$$
\varepsilon_{f}=\left[\left(\sigma_{0}-\sigma_{i}\right) / K+\left(\sigma_{e} S^{1 / 2} / K d^{1 / 2}\right)\right]^{1 / n} .
$$

For simplicity, let $n=1$ for the case of linear work-hardening, then $\mathrm{Eq}$. (4) reduces to,

$$
\varepsilon_{f}=\left(\sigma_{0}-\sigma_{i}\right) / K+\left(\sigma_{c} / K(s / d)^{1 / 2}\right.
$$

Eq. (5) has been used to predict the impact properties of the $\operatorname{Ir}-0.3 \% \mathrm{~W}$ alloys, and the predictions are now compared with the experimental results previously presented.

\section{Grain-Size Effect}

At a given test condition, Eq. (5) predicts that $\varepsilon_{f}$ will decrease with an increase in grain size $d$. This is in agreement with the data

${ }^{22}$ P. Ludwik, Elemente der Technologischen Meibank, Ver1ag Von Julius, Springer, Berlin, 1909. 
correlating impact elongation and fracture mode with grain size (Fig. 12). Furthermore, the impact elongation $\left(\varepsilon_{f}\right)$ should be a function of square root of grain size, d, according to Eq. (5). A linear relation exists between $\varepsilon_{f}$ and $d^{-1 / 2}$ for the WG specimens which showed grain-boundary fracture when impact tested at $1350^{\circ} \mathrm{C}$ and 280 fps (Fig. 16). The linear relation also holds quite well for the DOP-4 specimens, even though they exhibited ductile rupture in the fine-grain-size range.

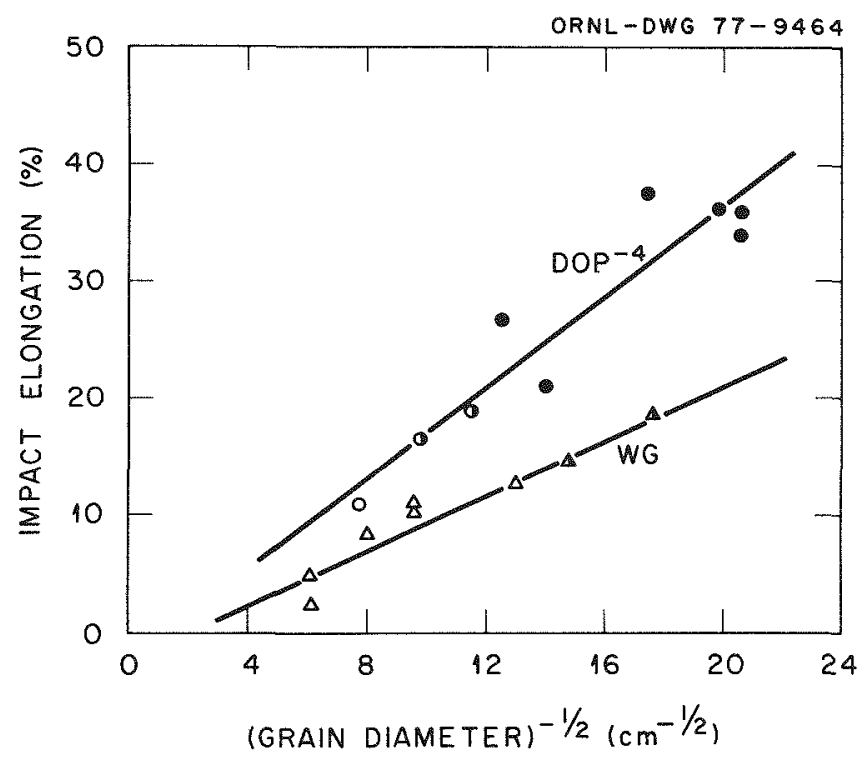

Fig. 16. Impact Elongation as a Function of Square Root of Grain Diameter for DOP-4 and Undoped (WG) Ir $-0.3 \% \mathrm{~W}$ Alloys. Open symbols for mainly GBS, filled symbols for mainly $\mathrm{TF}$, and half-filled symbols for mixed fracture of $\mathrm{GBS}$ and $\mathrm{TF}$.

\section{Dopant Effect}

As already discussed in this section, the DOP -4 dopants such as thorium segregate to and improve the coherent strength of the grain boundary, This is also manifested by measureing the slope of the two curves in Fig. 16, which shows that $\sigma_{c}[\mathrm{Eq} .(5)]$ for the DOP-4 alloy may be higher than the undoped alloy by $60 \%$. Also, the dopants retard grain growth in the DOP -4 alloy through dopant segregation and precipitation of second-phase particles; thus in DOP-4 alloy the grain structure 
was much finer than that of the undoped alloy under the same heat treatment condition. In Eq. (5), both and increase in $\sigma_{c}$ and a decrease in $d$, improve the fracture ductility. By a combination. of these two effects the impact properties of DOP-4 are greatly improved.

\section{Test Temperature and Velocity Effects}

Both $\sigma_{i}$ and $K$ increase with a drop in test temperature or an increase in strain rate. ${ }^{23}$ Both of these lower $\varepsilon_{f}$ in Eq. (5). This prediction also agrees with the impact data (Figs. 9 and 11).

In summary, the impact properties of the DOP -4 and undoped Ir $-0.3 \% \mathrm{~W}$ alloys can be correlated by $\mathrm{Eq}$. (5), which is derived on the basis of stress concentration at grain boundaries.

\section{SUMMARY AND CONCLUSIONS}

The Ir $0.3 \% \mathrm{~W}$ alloy has been doped with minor alloying additions for the purpose of developing improved cladding material for space radioisotopic heat sources operating up to $1450^{\circ} \mathrm{C}$. The dopants were thoroughly mixed with iridium powders, compacted, sintered, then arc or electron-beam melted. A total of 10 doped alloys were prepared; the DOP-4 alloy containing $40 \mathrm{ppm} \mathrm{A}, 30 \mathrm{Th}, 80 \mathrm{Fe}, 16 \mathrm{Ni}$ and $75 \mathrm{Rh}$ was the most resistant to brittle fracture associated with grainboundary separation on tensile testing at slow strain rates. In addition, the DOP-4 dopants improve the fabricability, raise the recrystallization temperature, and retard the grain growth at high temperatures.

Impact-testing equipment has been developed for testing materials in controlled atmospheres at temperatures to $1400^{\circ} \mathrm{C}$ at impact velocities as high as $90 \mathrm{~m} / \mathrm{s}$ (300 fps) (which is equal to a strain rate of $7200 / \mathrm{s}$. The impact properties of DOP-4 and undoped (WG) Ir $-0.3 \% \mathrm{~W}$ alloys were determined as a function of grain size, test

${ }^{23}$ R. W. Swindeman, Low-Strain Tensize Behavior of Type 304 Stainless Steel (Heat 9T2796), ORNL/TM-5245 (February 1976). 
temperature, impact velocity and long-term heat treatment. The brittle grain-boundary fracture is always promoted in these alloys by a decrease in test temperature or an increase in strain rate or grain size. A11 these results can be correlated by Eq. (5), which is derived on the basis of stress concentration at grain boundaries.

The impact test results (Tables $7-11$ and Figs. 9-15) clearly indicate that the impact properties of the DOP-4 alloy are far superior to those of the undoped (WG) alloys. The improvement is due to combined effects of segregation of beneficial dopants (such as thorium) to grain boundaries and a refinement of grain structure through dopant segregation and precipitation of second-phase particles. The superior impact properties of DOP -4 alloy, measured by uniaxial impact testing, are confirmed by the biaxial impact tests at LASL and by the MHW/FSA impact tests at GE. The development of the DOP-4 alloy greatly increases the safety margin of the MHW heat sources; therefore, the NRA/ERDA has decided recently to use this alloy to contain the heat source for the Mariner/Jupiter-Saturn mission scheduled for 1977.

\section{ACKNOWLEDGMENTS}

The authors gratefully acknowledge R. G. Donnely and A. C. Schaffhauser for program management and support. Thanks are due to J. F. Newsome for technical assistance; Metals Processing Group under R. L. Heestand for alloy preparation and fabrication; D. E. Harasyn for long-term heat treatment; C. L. White for Auger analysis; J. C. Franklin for SSMS; J. I. Federer for powder preparation; and W. H. Farmer for Metallography. We especially thank D. W. Ramey for loaning the gas gun to us.

The authors are grateful to C. O. Tarr of NRA/ERDA for program monitoring and technical discussion. We thank the personnel at Mound Research Laboratories, and FSA fabrication, and the General Electric Co., Space Division, for FSA/MHW impacting and recording the test results. We thank J. H. DeVan, G. M. Slaughter, R. C. Williams and J. M. Leitnaker for reviewing the technical content of this manuscript, 
George Griffith for editing and Gail Golliher for preparing the manuscript for publication. 
Blank page 
ORNL-5290

Distribution

Category UC-25

INTERNAL DISTRIBUTION

1-2. Central Reserach Library

3. Document Reference Section

4-13. Laboratory Records Department

14. Laboratory Records, ORNL RC

15. ORNL Patent office

16. D. N. Braski

17. C. R. Brinkman

18. J. A. Carter

19. F. L. Culler

20. J. E. Cunningham

21. J. H. DeVan

22. J, R. DiStefano

23. R. G. Donnelly

24. J. I. Federer

25. G. M. Goodwin

26. $I_{2} P$. Hammond

27. D. E. Harasyn

28. R. L. Heestand

29. R. F. Hibbs

30-32. M. R. Hill

33-37. H. Inouye

38. J. R. Keiser

39. E. Lamb

40. J. M. Leitnaker

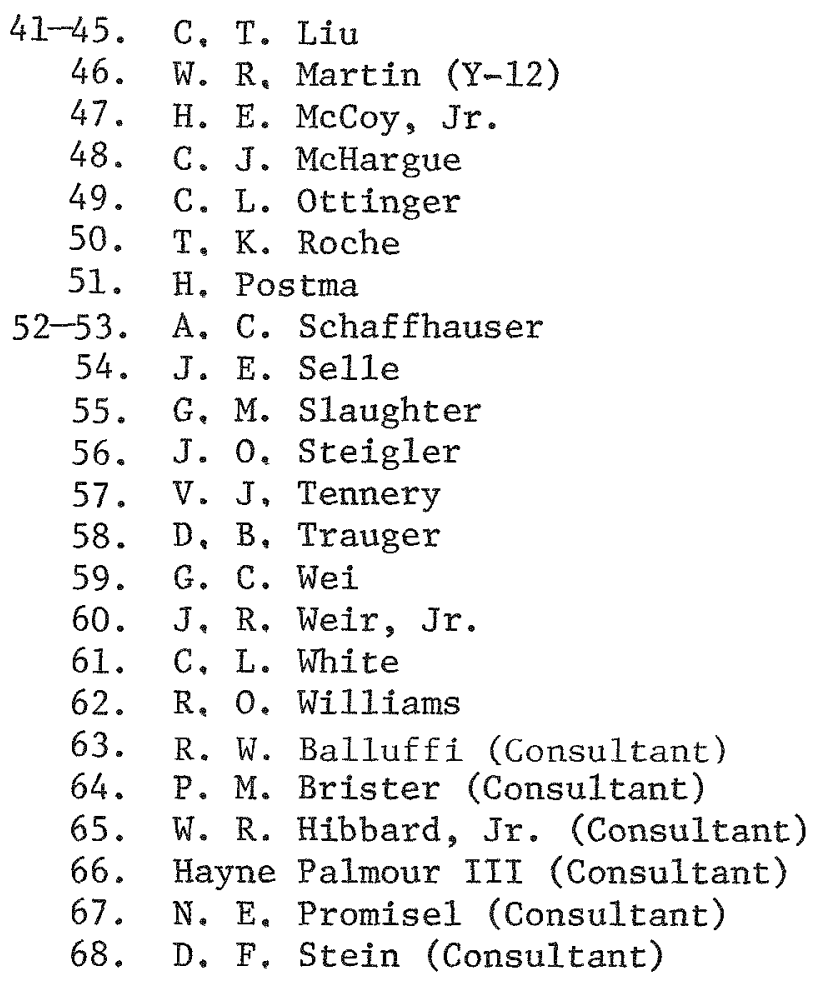

EXTERNAL DISTRIBUTION

69. AiResearch Manufacturing Company of Airzonia, 402 South 36 th Street, P. O. Box 5217, Phoenix, AZ 85010

J. E. McCormick

70. Battelle Memorial Institute, 505 King Avenue, Columbus, OH 43201

C. Alexander

71. Fairchild Space and Electronics Company, Germantown, MD 20767 A. Schock

72. General Electric Company, Materials Technology, Energy Systems Programs, 1 River Road, Schenectady, NY 12345

R. G. Frank 


\section{EXTERNAL DISTRIBUTION}

73. General Electric Company, Nuclear Programs, P. O. Box 8661, Philadelphia, PA 19101

E. W. Williams

74. Gulf Energy and Environmental Systems, P. 0. Box 608, San Diego, CA 92112

N. Elsner

75. Kirtland Air Force Base, NM 87117

Directorate of Nuclear Safety

76-77. Los Alamos Scientific Laboratory, P. O. Box 1663, Los Alamos, NM 87545

S. E. Bronisz

S. Hecker

78. Minnesota Mining and Manufacturing Company, 2501 Hudson Road, St. Paul, MN 55119

E. F. Hamp1

79. Monsanto Research Corporation, P. O. Box 32, Miamisburg, OH 45342

E. W. Johnson

80. Sunstrand Energy Systems, 4747 Harrison Avenue, Rockford, IL 61101

E. Kreuger

81-82. Teledyne Energy Systems, 110 W. Timonium Road, Timonium, MD 21093

W. J. Barnett

W. Osmeyer

83-93. ERDA Division of Nuclear Research and Applications, Washington, DC 20545
R. T. Carpenter
G. A. Newby
T. J. Dobry
B. J. Rock
W. D. Kenney
C, 0. Tarr
A. P. Litman
N. R. Thielke
J. J. Lombardo
E. J. Wahlquist
A. L. Mowery

94. ERDA Oak Ridge Operations Office, P. O. Box E, Oak Ridge, TN 37830

Research and Technical Support Division

95-332. ERDA Technical Information Center, P. O. Box 62, Oak Ridge, TN 37830 For distribution as shown in TID-4500 Distribution Category UC-25 Materials 